\title{
Namibian Kiche Duits: The Making (and Decline) of a Neo-African Language
}

\author{
Ana Deumert \\ University of Cape Town
}

\begin{abstract}
This paper provides the first overview of the history, sociolinguistics, and structures of Namibian Kiche Duits (lit. "kitchen German"), which is today a dying contact variety. The analysis draws on archival records, colonial publications, and memoirs, as well as over 120 sociolinguistic interviews conducted in 2000. Early varieties of Namibian Kiche Duits emerged from 1900 under German colonial rule. The language was used primarily for inter-ethnic communication within the work context. However, speakers also "crossed" playfully into Kiche Duits in a number of within-group speech genres (competition games, scolding, banter, etc.), thus appropriating the colonial language-alongside cultural borrowings (Truppenspieler, "traditional" dress) - for new in-group practices. These within-group uses contributed to the linguistic stabilization of the language as well as the formation of new (post-)colonial (neo-African) identities.
\end{abstract}

The data collection of [...] overseas varieties of pidginized and creolized forms of German is still in its infancy. Some fieldwork could still be carried out but time for linguistic rescue work is running out rapidly (Mühlhäusler 1984:56).

\footnotetext{
I would like to thank Paul Roberge and Hans den Besten for asking me over dinner in July 2008 about my work on non-matrilectal German in Namibia. I had published initial results from my fieldwork-focusing on one particular linguistic feature (past participles) and markedness theory - but never seemed to find the time to write a broader and more sociolinguistic/historical paper that would provide the necessary context for the more strictly linguistic analysis. Paul and Hans, thank you for reminding me that this paper still needed to be written! Thanks are also due to Susan Levine for drawing my attention to flash fiction as a literary style well suited to anthropological observation (see the appendix below which celebrates and acknowledges those who participated in this research); and to Nkululeko Mabandla for helping me - yet again - with my story line. All shortcomings and mistakes are, as always, my own responsibility.
}

(C) Society for Germanic Linguistics 
Ich bin Duitse vrouw. Alte Duitse vrouwe sei. Viele Duitse leute gearbeiten (Petrina, Swakopmund 2000). ${ }^{1}$

\section{Introduction: Blind Spots.}

Apart from Mühlhäusler's $(1979,1983,1984)$ work on Pidgin German in New Guinea and Kiautschou, Volker's $(1982,1989$, 1991) publications on Rabaul Creole German (Unserdeutsch, 'Our German'), and more recently Engelberg (2008), there has been little interest in the investigation of German-based contact varieties in the former German colonies. The silence becomes absolute when one looks at the African colonies: Togo, Cameroon, German East Africa (present-day Tanzania, Burundi, Rwanda), and German South West Africa (present-day Namibia). What was the linguistic impact of German colonial rule on the African continent?

Namibia was by far the most important overseas territory for the development of German-based contact varieties. It was Germany's only settler colony, and exposure to German thus extended beyond schools, mission stations and the occasional contact with colonial administrators. Employment relationships in particular created opportunities for informal/untutored language acquisition which continued beyond Germany's official reign: many German settlers remained in the territory after World War I and their descendents continued to form an economically and politically influential, as well as privileged, minority within Namibian society throughout the 20th century.

This longstanding and intense contact situation notwithstanding, linguists have generally argued that the German settlement had little impact on local linguistic repertoires. Thus, Maho (1998:170) states in his overview of Namibia's languages: "the German language does not

1 'I am a German woman. An old German woman. I worked for many German people'. Transcriptions in this paper reflect salient pronunciation features of Kiche Duits orthographically; this includes consonant cluster simplifications, word final apocope, loss of rounding in front vowels, as well as interference from Afrikaans. Sentence boundaries are marked by a full stop and capital letters; commas are used to indicate intonational segmentation; omissions are indicated by $[\ldots]$. Capitalization in the transcripts does not follow standard German rules for capitalization. Only names of places, people, and languages/ ethnic signifiers are capitalized. 
seem to have spread much outside of the German descendant population." Shah (2007:21) notes that German remained the language of a privileged white minority with only "few Blacks" speaking German (also Gretschel 1995), and Owens (2008:236) described non-matrilectal German in Namibia as structurally and functionally highly restricted: ${ }^{2}$

In businesses run or heavily patronized by ethnic Germans, one had for decades encountered black employees speaking an accented, functional German with unstable, Afrikaans-influenced grammar, and a vocabulary largely limited to the dealings in that business. [...]. Blacks with broad, nuanced linguistic competence in German were rare.

While forms of non-native German have certainly been around "for decades" and show varying levels of interference from Afrikaans (an important L2 in Namibia), the vocabulary and proficiency of many of its speakers clearly exceeds "the dealings in that business." This is not to say that what is locally known as Kundendeutsch ('customer German') does not exist. However, non-native German in Namibia cannot be reduced to such varieties, which consist of little more than a few stock phrases and vocabulary items.

Of the over 120 speakers interviewed for this study, all were able to discuss a wide range of topics in German during in-depth sociolinguistic interviews. Their competence, while showing structural reduction as well as contact-based innovations, was sufficiently "broad" and "nuanced" to narrate their life and family histories, to discuss politics and social change, to tell African folk tales, and to explain a wide range of cultural practices, ranging from dress to food, from wedding ceremonies to initiation rites. Why did these competencies remain invisible in the literature on German in Namibia?

Nora Schimming-Chase, Namibia's former ambassador to Berlin, highlights in her critical epilogue to Wentenschuh's 1995 photographic essay-Namibia's Germans. History and Present of the German Language Community in the South-West of Africa-how German-speaking

${ }^{2}$ Apartheid race classifications distinguished White, Black, Coloured (mixed African-European origin), and Asian. In this paper I use these terms when referring to apartheid policies. 
Namibians of non-European origin were marginalized and "silenced" in traditional accounts of the German speech community in Namibia:

Who are the "Germans" in Namibia? Those Namibians who speak German as their mother tongue? Those who have German ancestry, or only those with German ancestry and white skin? Or does this include everyone who, because of their own wish or our history, adopted German [...]? The author [Wentenschuh] refers to Black Namibians of German ancestry only once. This is significant as it is (almost) a continuation of an old habit to ignore their existence. However, we must applaud him for mentioning them at all (p. 270). ${ }^{3}$

Whether of mixed parentage or "purely African," the colonial project consistently constructed indigenous populations as "the other," and expressed strong disdain for so-called "trousered Africans" who adopted and appropriated cultural and/or linguistic aspects of colonial culture (Spear 2003). Thomas (1994) has argued that relics of these attitudes are still with us and create "blind spots" in our academic vision. They focus our attention on what is considered "truly African" (or "indigenous"), thus ultimately denigrating and marginalizing those new social and linguistic practices and repertoires that emerged across Africa as a result of the colonial experience.

The complex sociolinguistic competencies speakers displayed in the interviews do not show themselves easily in inter-ethnic social contexts such as workplaces, which were the only places were Africans and Europeans interacted on a regular basis. The overt power relationships of such spaces led to limited conversational interaction and the disenfranchised remained invisible to those who commanded power and prestige in the colonial society. In several cases employers of those I had interviewed were ignorant of their employees' linguistic skills, referring to their abilities dismissively as ja, ein paar deutsche Worte ('yes, a few German words'). Such misconceptions on the side of employers are, however, only partially a result of the, often limited, communicative

\footnotetext{
${ }^{3}$ A note on translations: most of the original German material quoted in this article is given in the English translation of the author. Only quotes from the field recordings, which are of direct linguistic interest, are given in both German and English.
} 
demands of the work contexts and the pervasive ideologies of colonial thinking: some participants would deliberately underplay their linguistic skills as it meant that employers would talk more freely in front of the staff who could obtain potentially important information this way. This paper seeks to document these hidden language skills.

Several speakers referred to their variety of German as Kiche Duits, that is, Küchendeutsch ("kitchen German"), showing loss of rounding in the front vowel [y] > [i] and using the Afrikaans pronunciation for "German." Speakers of Kiche Duits (often shortened to Duits) came from different language groups, primarily Otjiherero and Khoekhoe, and the majority were born in the 1920s and 1930s; the youngest speakers in the 1950s. Younger Namibians, who had the advantage of an improved school system that gave them formal access to Afrikaans and English, tend to prefer these languages for interethnic communication. This development was supported by the increasing multilingualism of matrilectal German speakers and the general shift toward English after Namibia's independence. Older members of the German community, on the other hand, were (and are) often monolingual and insisted on the use of German within their houses, businesses or workshops. This made the acquisition of German a necessity for their workers. Kiche Duits is a marginal language in the sense of Reinecke (1937), and today a dying contact variety (on contact languages and language endangerment, see Garrett 2006).

In this paper I present the first historical and sociolinguistic overview of Kiche Duits. Sections 2-4 reconstruct the historical background. Section 5 outlines the fieldwork that was conducted in 2000. Section 6 describes contexts of acquisition. Sections 7 and 8 look at various aspects of post-colonial "crossing" in Namibia; that is, the sometimes playful and always socio-symbolically meaningful appropriation of linguistic and cultural out-group practices. Section 9 provides an overview of salient linguistic structures and innovations. The final section (10) situates Namibian Küchendeutsch within current debates on contact

${ }^{4}$ In a previous paper (2003) I used the term Namibian Black German interchangeably with the standard German variant Küchendeutsch. I no longer consider the etic term Namibian Black German-which reflects an archetypal division of Black-White-as appropriate. In this paper I only use the emic designation. 
languages, addressing the perennial question of whether one should now report the "discovery" of a "new" German pidgin language.

\section{Namibia: A Historical Overview.}

With a territory of over 800,000 square kilometers and a population of just over 1.8 million (2001 Census), Namibia is a sparsely populated country. Information on Namibia's pre-colonial history is scarce. The oldest inhabitants of Southern Africa were groups of hunter-gatherers, the so-called San communities (Bushmen in older texts). During the last centuries of the first millennium BCE pastoralist Khoekhoe communities (Hottentots in older texts) moved southwards from Northern Botswana, and some of these groups eventually settled in southern and central Namibia. The languages spoken by these two groups are referred to as Khoesan. However, they do not form a genetic-linguistic entity in the sense of, for example, Indo-European or (Ba)Ntu. ${ }^{5}$ Instead, these languages are believed to constitute a linguistic area, that is, similarities between them are the result of large-scale diffusion processes rather than genetic relatedness (Güldemann \& Vossen 2000). In Namibia, Khoesan languages are spoken by groups such as the Namadama (Nama/Damara) and Oorlams (Haacke et al. 1997; Maho 1998:103f.).

Ntu-speaking groups entered Namibia during the 17th century from the north and soon established themselves in the northwestern and central parts of the country. Speakers of Oshiwambo and Otjiherero are pastoralists, while groups in the Caprivi area (for example, speakers of Rukawango and Silozi) depend on agriculture and fishing.

\footnotetext{
${ }^{5}$ The term Bantu has pejorative overtones in southern Africa due to its use by the apartheid government (for example, Bantu administration, Bantu education, Bantustans). The term was originally introduced by W. H. I. Bleek to illustrate the fact that the languages thus grouped together share a common root $* n t u$ 'person' ( $b a$ - is a class 2 noun class marker which is used in some of the languages and indicates plural, for example, isiXhosa abantu 'people'). To avoid the political-pejorative overtones of the term Bantu, I follow the usage in Wagner (1935) and refer to the Ntu languages. This allows the maintenance of Bleek's original language-historical motivation for the term. An alternative suggestion has been to use the term Sintu, where $(i) s i$ - is a Nguni class 7 prefix which refers to languages; for example, isiXhosa 'the Xhosa language', amaXhosa 'the Xhosa people'.
} 
From the beginning of the 19th century so-called Oorlam groups entered Namibia from the northwestern Cape (South Africa). The Oorlams were of mixed origin, consisting of (Cape) Khoekhoe, descendants of mixed settler-slave/settler-Khoekhoe unions, runaway slaves and Cape outlaws. These communities were bilingual (Cape Dutch/Afrikaans and Khoekhoe) and settled primarily in southern and central Namibia, where they intermarried with local Khoesan-speaking communities. ${ }^{6}$ Another group of mixed European-Khoekhoe ancestry that entered from South Africa were the Rehoboth Basters who settled in Namibia in the 1870 s.

European colonization began in the early 19th century when traders and missionaries entered the territory of present-day Namibia. In 1878 the British Cape Government annexed the area of Walvis Bay, and the rest of the coastal region was purchased by the German trader Adolf Lüderitz from the local Nama chief Joseph Fredericks for one hundred pound sterling and 200 rifles in 1883 (Gründer 1991:80). In 1884, the German Reich took over Lüderitz's possessions, granted the land the status of a protectorate, and began to expand inland.

Increasing tension between German officials and the Ovaherero culminated in the outbreak of military conflict in January 1904 (the socalled "Herero-German War"). The Ovaherero were defeated at the Waterberg in August 1904 and driven-following an extermination order of General van Trotha-into the Omaheke, a desert-like area where many died of starvation. The survivors were sent either to prisoner of war camps, or to the uninhabitable Shark Island near Lüderitz. Many more died. Oorlam and Namadama groups joined the struggle against colonial rule in 1905 and the war ended in 1908 with the defeat of these groups. About $80 \%$ of Ovaherero and between 35 and $50 \%$ of Oorlam and

\footnotetext{
${ }^{6}$ Following Deumert (2004), I use the term Cape Dutch/Afrikaans to refer to the continuum of Dutch-based contact varieties that existed in South Africa and Namibia until the early 20th century.

${ }^{7}$ In this paper I follow Mafeje (1991) and use emic terminology when referring to groups of people (Ovaherero 'the Herero people', singular Omuherero) and their languages (Otjiherero 'the Herero language'). Khoekhoe is used as the short form of the now official name Khoekhoegowab (following Haacke et al. 1997). Namadama is the term for people of Nama and Damara descent who speak Khoekhoe (Haacke \& Eiseb 1999). The majority of Khoekhoe speakers interviewed were of Damara descent.
} 
Namadama died in the war (Bley 1996:150f.). As noted by Jamfa (2008:202), it was a "war of extermination, designed to annihilate," and the war is today considered a case of genocide (Cooper 2006). ${ }^{8}$

Germany lost its colonial possessions after WWI, and from 1920 onward South Africa administered Namibia under a C-class mandate (granted by the League of Nations). After WWII South Africa refused UN requests to place Namibia under a trustee agreement, and instead implemented its own apartheid legislation in the mandated territory. A national liberation movement emerged in the 1950s, SWAPO (South West African People's Organization). In 1966 when South Africa ignored the UNs decision to revoke the South African mandate for Namibia, SWAPO began with guerilla attacks from the north. The struggle for independence intensified in the 1970s, and in 1978 resolution 435 was passed by the UN Security Council, containing a detailed plan for Namibian independence. Resolution 435 was finally implemented in 1989, and Namibia declared its independence on March 21, 1990, "after twenty-nine years of German colonial rule and a further seventy-five years of South African occupation" (Silvester 2005:271).

\section{Matrilectal German in Namibia.}

German settlers arrived in Namibia from the 1890s onwards (Rohrbach 1907:245). The early settlers originated mostly from the East Low German dialect area and came from the social and economic fringe of German society (see also Deutsche Kolonialzeitung 1890:96).

Until about 1900 English- and Cape Dutch/Afrikaans-speaking farmers from South Africa constituted an important group among the colonial population. The presence of "non-German elements" prompted the Reich to embark on a deliberate settlement policy, and the Germanspeaking population increased by over 300\% between 1903 and 1913 (see table 1, and also Walthers 2002:10). Settlement concentrated largely on the southern and central regions of the country, while the northern region ("Ovamboland") remained under indirect rule.

\footnotetext{
${ }^{8}$ Germany has been reluctant to acknowledge its historic responsibility for the genocide, and in 2003 the Herero People's Reparations Cooperation filed a lawsuit in the United States, alleging violations of international law. A hesitant apology was finally issued by Germany in 2004 .
} 


\begin{tabular}{|cccc|}
\hline Year & Total colonists & No. of Germans & $\%$ of Germans \\
\hline 1891 & 622 & 310 & $50 \%$ \\
\hline 1894 & 969 & 614 & $63 \%$ \\
\hline 1895 & 1774 & 846 & $48 \%$ \\
\hline 1896 & 2025 & 932 & $46 \%$ \\
\hline 1899 & 2872 & 1879 & $65 \%$ \\
\hline 1901 & 3643 & 2223 & $61 \%$ \\
\hline 1903 & 4682 & 2998 & $64 \%$ \\
\hline 1907 & 7110 & 4929 & $69 \%$ \\
\hline 1909 & 11791 & 9283 & $79 \%$ \\
\hline 1911 & 13962 & 11140 & $80 \%$ \\
\hline 1913 & 14830 & 12292 & $83 \%$ \\
\hline
\end{tabular}

Table 1. German colonists in Namibia (Oelhafen 1926:110-111).

The number of German speakers dropped to about 8,000 after WWI when all colonial government employees were repatriated following Germany's loss of its colonial possessions. However, by 1936 the community had grown again to between 9,000 and 12,000 (Hintrager 1939). German-medium schools continued to exist under South African rule and German could still be used in dealings with the new administration (protected by the 1923 London Agreement between Germany and South Africa). In 1984 German was officially recognized as the third official language within the administration for Whites. Upon independence in 1990, English was declared as the national and official language of the country (see Harlech-Jones 1990, Beck 2006). Today, the Germanspeaking population is just under 20,000 (2001 Census, see table 2). 


\begin{tabular}{|lr|}
\hline Language & $\%$ of speakers \\
\hline Oshiwambo & $48.5 \%$ \\
\hline Rukavango & $9.7 \%$ \\
\hline Otjiherero & $7.9 \%$ \\
\hline Silozi & $5 \%$ \\
\hline Setswana & $0.3 \%$ \\
\hline Khoekhoegowab (Khoekhoe) & $11.5 \%$ \\
\hline Other Khoesan languages & $1.2 \%$ \\
\hline English & $1.9 \%$ \\
\hline Afrikaans & $11.4 \%$ \\
\hline German & $1.1 \%$ \\
\hline
\end{tabular}

Table 2. Languages groups in Namibia (Census 2001).

Their minority status notwithstanding, German speakers have always been highly visible and influential in Namibia, especially within the urban environment. Thus, when the American consul to South Africa visited Namibia in 1939, he noted:

Although Germans as a whole constitute only a third of the [White] population, they are as individuals very active and enterprising and occupy positions of economic and social influence in their respective communities out of proportion to their numbers. They are not primarily farmers $[\ldots]$ but $65 \%$ of trading and professional licenses are held by Germans. Thus it is that (except for the American motor cars everywhere) the general impression given by South West African towns is that they are German settlements. The streets have German names and are lined with German shops and stores. The hotels and pensions are German and serve German food and in the cafes German beer (locally brewed) is consumed by persons comfortably reading German newspapers. In Windhoek, for instance, the only daily paper is the German "Allgemeine Zeitung," while the English paper, the "Windhoek Advertiser" and the local Afrikaans paper appear twice a week only $[\ldots]$ in general the languages of the territory are Afrikaans in the country and German in the urban districts [...]. I myself spoke German almost entirely while in South West Africa as the simplest means of intercourse (Barron 1978:152-153).

Much of this description still applies today, especially in central Namibia (see Silvester 2005). 
For Namibia's close-knit German-speaking minority, language remains a central marker of their distinctive historical identity-an identity that sets them apart from Deutschländers or Dscherries (English "gerry;" Germans from Germany), and which is embodied in the use of a distinct extraterritorial form of German. This variety is commonly called Südwesterdeutsch, henceforth SWD.

Like any other variety, SWD is not homogenous and the frequency with which speakers use SWD variants correlates with age, social status/ education, level of formality, and interlocutors present. Those who have acquired Standard German in the school environment often show conscious avoidance of highly marked SWD features in more formal contexts-especially extensive borrowing from English and Afrikaans. Artisans and farmers have been identified as "typical users" of SWD; the variety is also prominent among the youth and thrives in school hostels, particularly among male speakers (Gretschel 1995; see also Brock 1990, Mühlhäusler 1993). Only limited (socio)linguistic research has been carried out to date. Nöckler (1963) and Pütz (2001) illustrate salient lexical features of SWD, drawing on written sources as well as "constructed" examples. Brock (1990), Riehl (2004), and Shah (2007) are more sociolinguistic in orientation and based on spoken language data. Their analyses, however, focus on the description of typical features and do not provide any information on frequencies of usage.

Contact effects are most clearly visible in the lexicon, which shows a high number of borrowings and calques from English and Afrikaans. African languages, which are the majority languages in the country (see table 2), have contributed only a few terms; these include mariva 'money' (< ovamariva, Otjiherero) and the adverb huga/huka 'a long time ago' (< huga, Khoekhoe), which functions as a temporal emphasis marker (die hat huga lange gegangen 'she went a very long time ago'). Less common is hakahana 'quickly' (< hakahana 'to hurry' Otjiherero; for example, die macht nicht hakahana 'she is not working quickly').

Grammatical restructuring has been moderate, affecting specific areas of grammar rather than the linguistic system as a whole. Among the features reported in the literature are the following (see Riehl 2004 and Shah 2007 for further examples): 


\section{MORPHOLOGY}

(a) merger of accusative and dative case (occasionally also loss of gender and plural marking in conversational speech, but rare and possibly linked to attrition);

(b) periphrastic possessive (dem Peter sein Auto 'Peter his car', also attested in varieties of German);

(c) future tense formation with gehen ('to go'; in analogy with English/Afrikaans, rather than the standard German future marker werden);

(d) the use of invariant was as a relative marker (< Afrik. wat; German requires the relative pronoun to be marked for gender and case; for example, SWD ein kleines kalb, was 'a small calf, which' instead of standard German ein kleines kalb, das [neuter, singular]);

(e) personal pronouns are frequently replaced by definite articles (der kann gut Herero 'that one [the-MASC] speaks Herero well', rather than er kann gut Herero 'he speaks Herero well'; also attested in varieties of German).

\section{SYNTAX}

(a) loss of verb-final in subordinate clauses after weil ('because'; in analogy to on-going changes in varieties of German as well as Afrikaans);

(b) non-obligatory use of the conjunction dass ('that'; possibly due to influence from colloquial varieties of Afrikaans where dat-dropping is common);

(c) changes in negative syntax; that is, in negative sentences with inflected modals and auxiliaries the negative adverb nicht typically precedes the object and occupies the position following the modal/ auxiliary (in line with negation in English and Afrikaans; for example, SWD du musst nicht das sagen 'you must not say that' vs. standard German du musst das nicht sagen);

(d) changes in the prepositional phrase, that is, the use of spurious prepositions (such as für in analogy with Afrikaans vir), as well as changes in preposition use (possibly due to interference from Afrikaans and English);

(e) occasional omission of constituents (SWD die Kinder sind in stadt 'the children are in town' vs. standard German die Kinder sind in der Stadt; possibly due to interference from English and, in some cases, language attrition). 
The matrilectal German community, while small in numbers, had a lasting influence in Namibia, especially in the central and centralnorthern areas where the majority of settlers lived. This includes towns such as Windhoek, Swakopmund, Okahandja, Gobabis, Omaruru, and Otjiwarongo, as well as the surrounding farmland (figure 1). The main indigenous languages are Khoekhoe and Otjiherero; however, Oshiwambo-speaking contract workers have also migrated into these areas. Afrikaans is the main language for groups of mixed European-African origin.

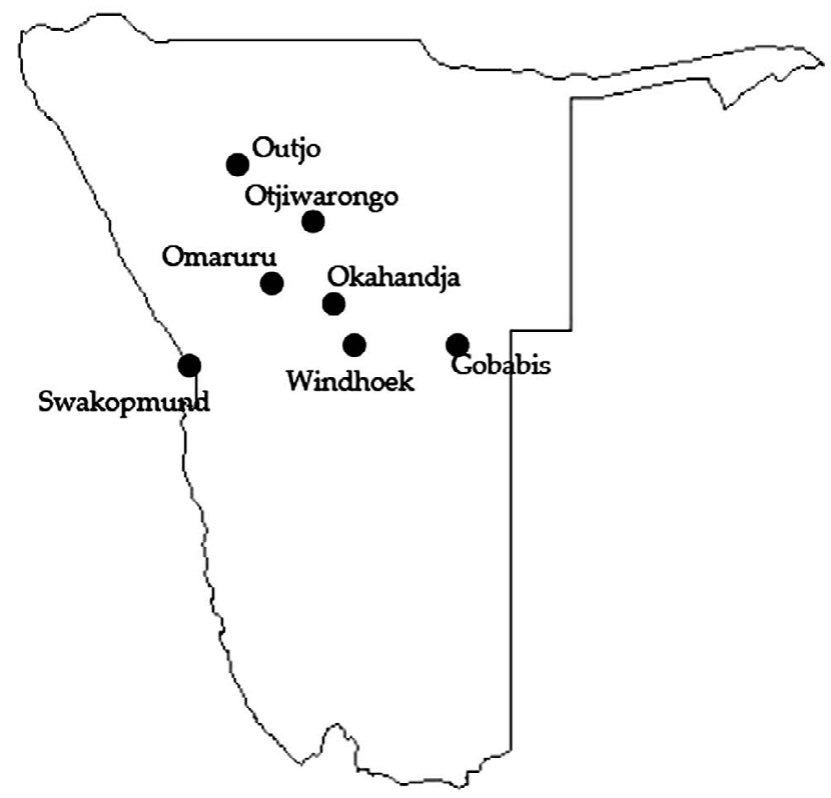

Figure 1. Central and central-northern Namibia.

\section{Historical Evidence: Non-Native German During Colonial Rule.}

\subsection{Acquisition of German I, Acrolectal Varieties.}

Initial colonization in Africa relied strongly on pre-existing lingua francas: in East Africa there was Kiswahili, in Namibia Cape Dutch/ Afrikaans, and varieties of Pidgin English were spoken in Cameroon and Togo. However, from about 1900 the colonial government actively encouraged and supported (via an independent colonial budget) the 
acquisition and use of German in all its territories (see Mühlhäusler 1993, and Mühleisen 2005, for a discussion of the underlying ideology; see also Sokolowsky 2004).

German was taught as a second language in Namibian mission schools from 1895, and following growing pressure from the colonial government the teaching of German was expanded over the years. The aim was to create "a German-speaking upper class" (eine Deutsch sprechende Oberschicht; Koloniale Rundschau 1913) on which the colonial government could draw for administrative purposes. In 1912, von König (pp. 623-624) provided a positive assessment of the situation in Namibia which compared favorably even to the Musterkolonie ('model colony') Togo:

Everywhere [that is, in all schools in the colony] special emphasis is put on the acquisition of German [...]. The indigenous languages are allowed only as vehicular languages if the teacher needs to explain himself to the students.

According to von König, about 3000 children and adults attended mission schools (including evening classes) at the time of his survey; this constituted about $10 \%$ of the estimated indigenous population in central Namibia (using the post-war population estimates given by Gründer 1991:121). Three main groups of pupils were found at the mission schools: (a) members of the African elite, (b) the offspring of inter-ethnic unions, and (c) those who were in the employ of the government or mission, or preparing for such employment. The following overview provides a rough sketch of these three groups of pupils; further research in mission archives is a desideratum.

\section{THE AFRICAN ELITE}

Members of the African elite were generally multilingual, with a solid German mission education and often presented themselves wearing European dress. Margarete von Eckenbrecher (arrived in Namibia in 1902) describes in her memoir Samuel Kariko, the son of the Ovaherero chief in Okombahe (near Omaruru), as follows:

Samuel Kariko was always very distinguished. Once he visited me, in a white suit, with a starched shirt, yellow riding boots, watch, handkerchief and walking stick [...]. He spoke German and Dutch well, his 
English and Namaqua [Khoekhoe] were not bad. He also wrote Herero and Dutch very well, his written German was moderate (1940:119).

Similarly Clara Brockmann (arrived in Namibia in 1907) narrates an encounter with the Khoekhoe Kaptein "Franz" who talked to her using "pure High German" (reines Schriftdeutsch, lit. 'pure written German'):

He wore clean European dress ... [spoke] flawless German. It was the first time that I heard the formal Sie ['you, formal'] out of the mouth of a native (1912:185).

\section{CHILDREN OF EUROPEAN/AFRICAN PARENTAGE}

As in other colonies, the sex ratio in Namibia was strongly biased toward men. Women made up only about one-fifth of the European population, and intermarriages as well as co-habitation with indigenous women were common among colonists (Oelhafen 1926:110-111; Walthers 2002: $34 \mathrm{ff}$.). The main concern of the colonial government was not the existence of sexual encounters as such-many of which were short-lived, exploitative and forced (see Gewald 1999:201-202) - but the children born as a result of such unions. Children of mixed origin were seen as a threat to the colonial order, which was based on a clear-cut legal and social distinction between natives/servants and Europeans/masters. In 1905, the German government forbade any further marriages between Africans and Europeans, and in 1907 the High Court in Windhoek declared all mixed marriages that had taken place before 1905 as null and void. This, however, did not change the reality of such interethnic unions. In 1909 alone 1,574 children were born of mixed parentage (Deutsche Kolonialzeitung 1910:486).

Some mission schools, such as the Augustineum in Okahandja, the Catholic Mission in Windhoek and the orphanage in Keetmanshoop, catered almost exclusively for mixed race children. Hilda, the granddaughter of a German father and a Khoekhoe-speaking mother, attended the Catholic Mission school in Windhoek in the 1930s and describes a strongly German-dominant school environment (interview 2000 in Swakopmund):

Aber, ehm, aber, und nachher wir bin so nach der schule gegangen, ham wir auch bei die swestern nur, nur Duits gesprechen, wir haben nur Duitse, eigentlich sin wir Duits aufgezogen. 
[But, ehm, but, and afterward we went to school, we only spoke German with the sisters, only German, we have only German, actually we were brought up German.]

This is reminiscent of the situation in Papua New Guinea where Unserdeutsch developed in the German-medium (Catholic) mission school environment (Volker 1982, 1991).

\section{COLONIAL EMPLOYEES}

Among those who received formal instruction in German at mission schools were also indigenous soldiers and policemen, as well as those to be trained as mission school teachers. Pastor Anz of the Lutheran church in Windhoek, for example, ran evening classes that trained indigenous employees for work as interpreters in the colonial administration (Deutsches Kolonialblatt 1902:143). District reports such as the following show that the colonial government succeeded in training local staff with varying levels of competency in German:

Keetmanshoop. The district has good interpreters among the policemen who have been working here for some years. Their knowledge is sufficient for simple translations. In addition, an indigenous teacher who speaks German well is used as an interpreter (Windhoek National Archives, ZBU 249, 18 December 1911).

Bethanien. At our office we have two natives who are able to translate even complex sentences. At the local mission a boy is currently being trained as translator. He will be appointed to the police once he has completed his education (Windhoek National Archives, ZBU 249, 28 November 1911).

\subsection{Acquisition of German II, Mesolectal, and Basilectal Varieties.}

In 1897 rinderpest destroyed the economic base of Otjiherero and Khoehoe-speaking pastoralists. Less than $10 \%$ of their herds survived, leading to severe impoverishment of these communities. Many were now forced to sell their labor to the newly arrived colonists or the colonial government in order to obtain food and shelter. This process laid the foundations for a society divided into colonial owners (of land, livestock, 
etc.) and African non-owners, a new laboring class (Bley 1996:124ff.; Werner 1998:43ff.; Gewald 1999:110ff.).

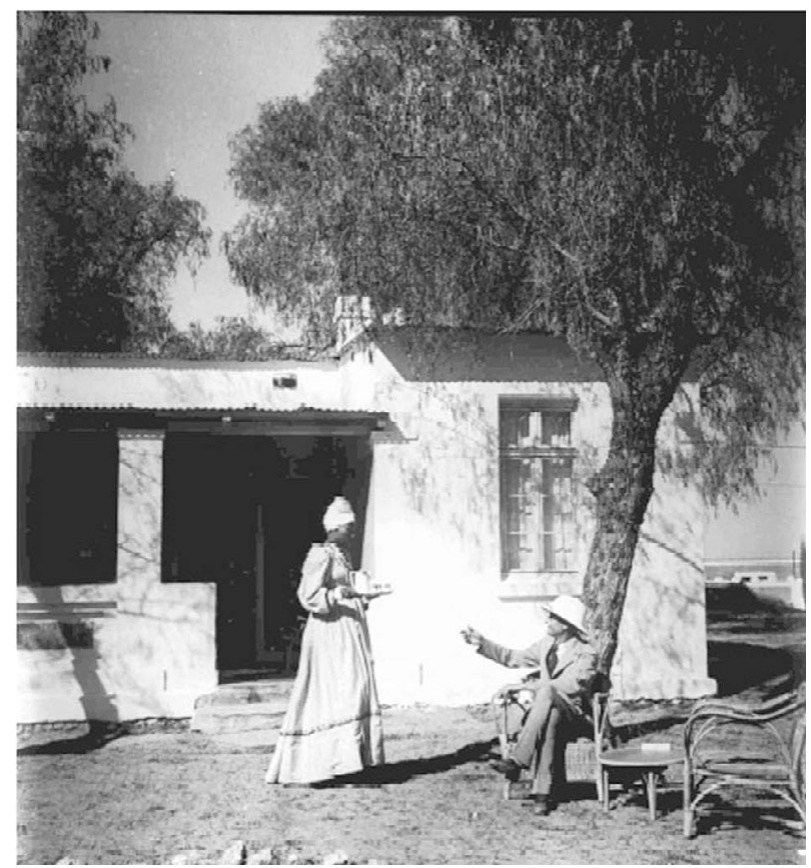

Figure 2. Domestic servants: An Omuherero woman serves coffee (Koloniales Bildarchiv no. 009-2071-08).

The increasing proletarization of the African population was actively supported by the colonial government through legislation: lands were confiscated and the right to own cattle was severely restricted; all Africans had to wear passes, and those without labor contracts were prosecuted as "vagrants," thus effectively creating a system of forced labor (Gründer 1991:122). By 1913 about 95\% of the African population in central and southern Namibia was classified as Lohnarbeiter ('wage laborers') by the colonial administration; ${ }^{9}$ of these $55 \%$ worked

\footnotetext{
${ }^{9}$ However, this high percentage, based on the number of passes issued, is likely to be an over-estimate as individuals were frequently given multiple passes and
} 
as domestic servants or farm workers, $34 \%$ in small factories, and $11 \%$ in the army or police (Oelhafen 1926:116-117; see also figure 2 above).

Colonists and workers did not usually share a common language. Colonial memoirs provide metalinguistic commentary and examples of different communicative responses to this situation. Three main media of inter-ethnic communication are documented in these texts: (a) mixtures of Afrikaans and German, (b) a macaronic Otjiherero-German jargon, and (c) the use of (structurally reduced) non-native forms of German.

\section{AFRIKAANS-GERMAN ADMIXTURE}

Cape Dutch/Afrikaans was brought to Namibia in the nineteenth century when Afrikaans-speaking groups of mixed descent, the Oorlams and later the Rehoboth Basters, migrated from the Cape to southern and central Namibia (see section 2). Structural similarities of Afrikaans and German supported from early on processes of relexification. Examples 1 and 2 come from the memoirs of Margarete von Eckenbrecher (op.cit.) and Ada Cramer (arrived in Namibia in 1906). Afrikaans relexified items are underlined; the sentences were reportedly uttered by Khoekhoe speakers.

(1) $\underline{\mathrm{Hu}}$ kan doch di gnae Frau so afsonderlicke Dinge frag, ons hat die goed gehad.

'How can Madam ask such strange things, we had the things' (von Eckenbrecher 1940:76). ${ }^{10}$

(2) Ossen banja weit hardloop.

'The oxen ran very far' (Cramer 1913:3). ${ }^{11}$

were known to drift in and out of employment, depending on opportunity and need.

${ }^{10}$ Afrikaans: Hoe kan tog mevrouw so afsonderlike dinge vra, ons het die goed gehad; German: Wie kann doch die gnädige Frau so absonderliche Dinge fragen, wir haben die Sachen gehabt.

${ }^{11}$ Afrikaans: Die osse het baie ver gehardloop; German: Die Ochsen sind sehr weit gelaufen. 
Under South African rule there was increasing dominance of Afrikaans in government, education, and the public domain; the continuing inmigration of White Afrikaans-speaking farmers established the language firmly within agricultural workplaces. Processes of relexification thus continued and mixed language forms are still common today in areas with a high percentage of Afrikaans-speaking Whites.

Extract 3 comes from an interview (2000 Omaruru) with Amon (L1 $=$ Khoekhoe), and shows extensive admixture from Afrikaans. Borrowings from Afrikaans are underlined, syntactic interferences in bold; word-initial /g/ is generally pronounced in line with Afrikaans as $[\mathrm{x}]$, not as German $[\mathrm{g}]$.

(3) Ich hab da bei Tsumeb gearbeit, daar bei bakkery, daar waar der brood, arbeiten. Ja, ich het daar gelern die Duits. Das is noch alte groot ouens daar bei lokasie wat noch Duits sprechen. Ich habe daar bei brood-hause gearbeit, daar by transporte gearbeit, dort bei Otavi. Toe los ich da die arbeit bei Otavi, dann kry ek eine plaase-arbeit, bei eine Duitse, Mr. H., der is oorlede, is net seine kinder nou bei die plaas, ich arbeit da bei tuin, bei die farm, grunde machen da hinten bei die tuin [...] nein, ons lebe nich' gut, baie honger hier, das is keine geld, das is nie arbeit in Omaruru nie

'Then I worked there in Tsumeb, there at the bakery, there where the bread, work. Yes, I have learnt German there. There are still old people there in the location who still speak German. I have worked there at the bread-house, there at the transport, there in Otavi. Then I leave the work in Otavi, then I get farm work, with a German, $\mathrm{Mr} \mathrm{H}$, he is dead, it is just his children now at the farm, I work there in the garden, at the farm, making the ground, in the back of the garden $[\ldots]$ no, we don't live well, much hunger here, there is no money, there is no work in Omaruru.'

Both Tsumeb and Otavi have a large Afrikaans-speaking population. Heavy lexical borrowing is typical in the local German community, and thus probably formed part of the input. However, matrilectal varieties never show the density of mixture reflected in 3 . 


\section{OTJIHERERO-GERMAN JARGON}

Lydia Höpker, who arrived in Namibia in 1913, described the macaronic jargon, a mixture of Otjiherero and German, which was used on her farm as "broken German mixed with bits of Herero" (mit Hererobrocken untermischtes gebrochenes Deutsch; 1997[1936]:13). Examples 4-8 come from her memoirs (1997[1996]), from a short story written by her husband, Carl Höpker (1913), as well as the memoir of Hilla von Flotow (1992) who arrived in Namibia in the 1930s, and Cramer's Kinderfarm (1942).

(4) Mister ba-vera tjirura sauf ongombe Mister SUBJ.-be sick ghost booze.root cattle seine omuti POSS medicine

'The mister is sick. He looks like a ghost. He drank the cattle's medicine' (C. Höpker 1995[1913]:10).

(5) Ungura ombrote stief mariva work bread much money

'Make bread, then you will get a lot of money' (L. Höpker 1997[1936]:100).

(6) Mister Ongue, Pavian kaputt gemacht mister leopard baboon broken made

‘The leopard has killed the baboon' (L. Höpker 1997[1936]:34).

(7) Missis, Missis, meine Kanadji-s Hunger, missis, missis my child-PL hunger, ich erst hapuhapu, dann ich kotocka I first swarm then I return

'Missis, Missis, my children are hungry. I will first take care of them, then I will come back' (von Flotow 1992:57). 
(8) Harrikana! Harrikana! Mister, mukuru grosse omburra! ${ }^{12}$ please! please! mister, god big roar!

'Help us! Help us! Mister, God sent us a heavy thunderstorm' (Cramer 1942:90-91).

The eye dialect in examples $4-8$ shows:

(a) lexical polysemy, for example, in 6 kaputt machen 'destroy (a thing)', with the semantic extension 'to kill (an animate being)', and in 4 saufen 'to booze' meaning 'to drink';

(b) grammatical reduplication (in 7 hapuhapu < Otjiherero ehapu 'swarm', class 5 noun);

(c) morphological reduction (reduction of Ntu noun class marking, tijruru from otjiruru, mariva from ovamariva; unmarked past tense, sauf);

(d) mixed forms such as kanadji-s < Otjiherero okandu 'small person' (class 12 noun) with German default plural $-s$ (and reanalysis of the noun prefix $o k a$ - as part of the stem);

(e) use of typical SWD lexical items such as stief ('very, many', which is used as an intensifier in SWD; probably North German origin);

(f) omission of constituents (pronouns, articles and VPs).

Evidence for this Otjiherero-German jargon is exclusively of a secondary nature and one might speculate that the same is true for many of such mixed, transient varieties that emerge ad hoc under the pressures of the situation. In those cases where the superstrate (here German) is not withdrawn, these forms are usually replaced by non-native approximations of the superstrate.

\section{NON-NATIVE VARIETIES OF GERMAN}

In 1914 Raimund Freiherr von Gleichen published a small booklet, providing those who considered settling in Namibia with practical advice. On the question of language, he remarked:

\footnotetext{
${ }^{12}$ This could be a corrupted form of orumbembera ('roar', Otjiherero), a possible misrepresentation by the German-speaking writer.
} 
The colloquial language is the German language. Almost all indigenous people understand German quite well (cited in Mühleisen 2005:32).

Descriptions and imitations of non-native varieties of German abound in the colonial literature, gradually replacing forms of "kitchen Herero" used by the colonists. Irle $(1911: 147,149)$ notes:

In the house one just speaks German. People can understand and mostly speak the kitchen German [Küchendeutsch], just as we spoke kitchen Herero in the beginning [...]. Earlier the natives [Eingeborenen] laughed about our broken Herero, now we laugh about their German; times are changing.

Lydia Höpker describes in her memoir not only the use of an OtjihereroGerman jargon, but also provides glimpses of the non-native varieties of German used by her workers. Example 9 shows omission of NP (determiner) and VP elements (inflected modal; copula) as well as phonological modification (consonant cluster simplification; the addition of word-final vowels in line with Ntu phonology). The use of Afrikaans moi/mooi ('nice') is typical for SWD in general; it formed part of the (matrilectal German) input (rather than showing admixture from Afrikaans).

(9) "Judas, why did you take me here?" I snorted after I recovered my spirits a little. "Judas, black sister see! White people but nice!" (Judas, swarze Swestera sehen! Weisse Mense doch moi!) he answered and just couldn't understand why I would rather have spent the night in the bush than with "nice white people" (1997[1936]:41).

Similar examples are reported in Ursula Ewest's (born 1909) locally published memoir Pad (1999). In example 10 the Khoekhoe-speaking farmhand Klaas uses a reduced form of German with frequent constituent omission (copula, article, auxiliaries). As in example 9 his speech also includes non-standard lexical items which occur in colloquial varieties of SWD: mooi, stief, kant (< Afrikaans, 'side'), miskien (< Afrikaans, 'maybe'). 
(10) [Context of the episode: The farmer Wolf had recently lost many of his sheep to wild animals and awaits Klaas' return anxiously]

Klaas welcomed them with a smile. Thank God, it can't be too bad. He brandished his hat and said "Morning, mister" (Morro [Otjiherero greeting], Mister), as if nothing had happened. "Yes, where have you been this night, how many sheep are missing?," asked Wolf.

More smiles. "Don't think any. Mister must just count." (Glaube keins. Mister muss mal zählen)

"But where were you tonight?"

"There, at mountains" (Da, bei Berge), he points vaguely in the direction.

"Why, which mountains?"

The smile disappeared. "Other side of fence. Much grass there. Sheep ate nicely. No wind between high mountains. Sheep slept there" (Andere kant Draht. Stief Gras da. Schafe mooi gefressen. Zwischen hohe Berge doch kein Wind. Schafe da geschlafen.) He looked a little insecure. Wolf was speechless. Klaas misunderstood that and said defensively "No sheep lost, otherwise perhaps many gone" (Kein Schaf verloren, sonst miskien stief weg) (p.90).

Varieties of non-matrilectal German continued to be spoken under the South African mandate. In 1946, the Chief Native Commissioner described the language skills of one Isaak Katjingengue, an Omuherero who worked as a driver for a Mr Feitelberg in Windhoek, as follows:

He [Isaak Katjingengue] speaks the three European languages [Afrikaans, English, German] easily and well, apart from his own language, and can read and write (Windhoek National Archives, A 50/59; June $25,1946)$.

And in 1942 Cramer noted:

All Hottentots [Khoekhoe] and Herero in German South West Africa under-stand German and can speak some, and us Germans speak only German with them (p. 19). 
Following the 1948 victory of the National Party, South Africa implemented apartheid in the mandated territory, thus continuing and intensifying earlier colonial policies of exploitation and segregation. Contact with German speakers was now restricted entirely to the work environment. Any forms of cohabitation were outlawed under the Immorality Act (1950), and African urban settlements (so-called townships) were moved to the peripheries of towns and cities, far away from White residential areas. ${ }^{13}$ Afrikaans became the dominant language of the new administration, was taught as a second language in the school system, and promoted as a lingua franca for inter-ethnic communication. However, many, especially urban, workplaces remained Germanspeaking and language learning continued: in the 1970 census over 12,000 Black Namibians reported speaking German (that was $2.1 \%$ of the total Black population; 26\% indicated knowledge of Afrikaans, and 8\% knowledge of English; Kleinz 1981:267ff.).

\section{Fieldwork.}

The fieldwork was carried out over five months during $2000 .{ }^{14}$ The main fieldsite was the coastal town of Swakopmund, which is colloquially referred to as kleines Deutschland ('little Germany'). Swakopmund has a high percentage of matrilectal German-speakers, and a carefully maintained German flair: there are German bakeries, cafes and restaurants, the daily Allgemeine Zeitung, German food and beer in the supermarkets, as well as numerous German associations (Gesangsverein 'choral society', Schützenverein 'shooting club', Kegelverein 'bowling club', etc.).

The urban structures of Swakopmund still reflect the rigid boundaries of the apartheid days: the town center, known as die dorp or das Dorf ('the village'), is almost exclusively White, as is the new residential area of Vineta. Until the late 1950s a mixed Black and Coloured area, referred to as die ou lokasie ('the old location') was situated in close vicinity to the town center. In the early 1960s separate residential areas

\footnotetext{
${ }^{13}$ In Namibia and South Africa the term township refers to (underdeveloped) urban living areas at the peripheries of towns and cities, which were reserved for non-Whites during apartheid.

${ }^{14}$ This fieldwork was generously supported by the National Research Foundation (South Africa) and the Graduate School at the University of Heidelberg (Germany).
} 
for Black and Coloured people were built in accordance with apartheid legislation at the urban periphery: Black residents were resettled in the new township of Mondesa; Coloured residents were resettled in a separate township called Tamariskia.

Kiche Duits speakers in Swakopmund were reached through local network contacts. According to the ethnographic principle of participant observation I took part in the daily life of the speakers, looked after children, and helped with household duties. I attended the church service on Sundays and was invited to birthdays and weddings. Most of the interviews took place at the houses of those to be interviewed and had the character of a friendly visit - often accompanied by a shared mealrather than a formal interview. Frequently family members and neighbors participated in the conversation, and several spontaneous group interviews were recorded in that way. Channel cues such as laughter, variation in pace and pitch, etc. also indicate the closeness of the recorded data to natural speech events. In conducting the interviews I generally used a mid-range speech level, but also found myself to engage in linguistic accommodation, including the use of features that I would consider ungrammatical in my native idiolect of German.

Topics ranged from questions about where and how German was learnt, when and with whom it was used, to family anecdotes, work experiences and gossip about employers, life under apartheid, the differences between life on the farms and in town, sociopolitical change, as well as the description of indigenous practices and customs, and the narration of traditional African folk tales. In addition, speakers were asked to repeat some of the sentences that were used by Georg Wenker in his 19th century survey of German dialects (to test for phonetic features) and to translate a few sentences from Afrikaans (which was known as an L2 by all speakers) into German (to test for lexicon and grammatical structures). This more formal part of the interview was usually interpreted as a competition or game, and frequently other family members or neighbors participated. Altogether 82 speakers were recorded in Swakopmund; a further 44 speakers were recorded in other towns in central Namibia (table 3, see also figure 1). 


\begin{tabular}{|lccc|}
\hline Town & Male & Female & Total \\
\hline Swakopmund & 38 & 44 & 82 \\
\hline Omitara & 4 & 1 & 5 \\
\hline Windhoek & 6 & 8 & 14 \\
\hline Omaruru & 4 & 3 & 7 \\
\hline Khorixas & 2 & 1 & 3 \\
\hline Usakos & 2 & 0 & 2 \\
\hline Rehoboth & 0 & 3 & 3 \\
\hline Outjo & 0 & 2 & 2 \\
\hline Walvis Baai & 2 & 6 & 8 \\
\hline Total & 58 & 68 & 126 \\
\hline
\end{tabular}

Table 3. Geographical location of participants. ${ }^{15}$

Participants usually had two first names, a German name (which was always used in interactions with Whites) and an African name (which was used interchangeably with the German name in the township). Below I use pseudonyms reflecting the German names of participants. All interviews cited in the remainder of this paper come from the fieldwork in 2000 .

\section{Contexts of Acquisition.}

\subsection{Learning German as Children.}

Although the work environment was by far the most important place for the acquisition of German some African Namibians acquired German as children, mostly as a result of being born of mixed African-German parentage. Their fathers and grandfathers were typically members of the colonial army who had settled in Namibia upon their discharge and married, or more commonly cohabited, with indigenous women. Many of the children and grandchildren born to such unions acquired some German in the home, and were subsequently sent to German mission schools for their education (see section 4.1).

15 Omitara is a farming area about halfway between Windhoek and Gobabis; Rehoboth is a town about 90 kilometers south of Windhoek; Usakos is a farming area about 100 kilometers east of Swakopmund; Walvis Baai is about 30 kilometers south of Swakopmund; Khorixas is about 120 kilometers southwest of Outjo. 
Extract 11 comes from an interview with Irmgard (born in the 1920s, L1 = Otjiherero), the daughter of a German farmer and an Otjihererospeaking mother. In 2000, when the interview was conducted, Irmgard was highly respected as a successful farmer in the mostly Germanspeaking community of Outjo. German has played an important role throughout her life, and has always been part of her identity.

(11) Ich ham so in schule, in Klein-Windhoek-schul, mein vater war ein Duitser, da hab ich von vater gelernt und dann in nach schule gegangen in Klein Windhoek, Katholische mission, da hab ich Duits gelernt [...] mein vater, der hat mich grossgemacht, selber, zur schule geschickt, später hat der immer mir besorgt bis zur nächste schule, der war, mit neunzig Jahren ist der gestorben [...] das Duits is doch im blut, man kann doch nicht vergessen

'I have [learnt] it in school, in the school in Little Windhoek [a suburb of Windhoek], my father was a German, thus I learnt from the father and then went to school in Little-Windhoek, Catholic mission, there I learnt German [...] my father, he brought me up, himself, sent me to school, later he always helped me for the next school, he was, he died when he was ninety [...] the German is in the blood, one cannot forget it.'

Similarly, Hilda (also born in the 1920s, L1 = Afrikaans; see 4.1) grew up with German. Her grandfather was a German soldier who had married a Khoekhoe-speaking woman. Like Irmgard's father he spoke German with his children, and also grandchildren.

(12) Interviewer: Und was haben sie mit ihrem opa gesprochen? Hilda: Duits, Duits, aber so bisschen auch Afrikaans dazwischen, ehm, so bisschen hat der angelern, dies Afrikaans war bisschen schwach, aber der hat Duits gesprechen, un die sohns ham, die kinder ham alle Duits gesprechen mit ihre vater, mein vater auch un so, wir ham bisschen schwach, wir ham bisschen schwach, aber wir ham, Duits, Afrikaans, so ham wir immer bisschen gemixt ne, das war eigentlich schlecht, man hat nie saubere Afrikaans kon sprechen, un auch nich saubere Duits, die ganze land is mal so, ehm, is immer so bisschen Duits. 
Interviewer: 'And what did you speak with your grandfather?' Hilda: 'German, German, but a little Afrikaans in between, ehm, he learnt a little bit. The Afrikaans was a little weak, but he spoke German, und the sons, the children all spoke German with their father, my father too, we [the grandchildren] are a little weak [in German], we are a little weak, but we speak it, German, Afrikaans, we always mixed a little, ne, that was actually bad, one could never speak pure Afrikaans, and also not pure German, the whole country is just like this, ehm, there is always a little German.'

In some cases within-family language transmission continued into the third generation. Flora, Hilda's daughter (born in the 1940s, L1 = Afrikaans), remembers speaking German to her grandfather (that is, Hilda's father) as a child. However, she (the first-born) was the only one among her siblings to do so.

(13) Ja, mein opa, oh mein opa war gut für mich immer, kaffee ham wir immer gemacht, lekker kaffee. Sag der: 'Komm her!' 'Ja, opa, ich komme!' [Laughter]

'Yes, my grandpa, oh my grandpa was always good to me, we always made coffee, nice coffee. He says: "Come here!" "Yes, grandpa, I'll come!'.'

It is important to remember that for those with German ancestry social interaction with members of the matrilectal German community was legally restricted under apartheid. Like Black Namibians, they remained at the periphery of society; politically disenfranchised, they lived in designated Coloured townships and were only allowed to enter White areas for purposes of work. Yet, in all these families, the Maletzkis, the Brockerhoffs, the Dentlingers, the Hagedorns-to name but a few common surnames - the German history is remembered (and often cherished) across generations.

The home was not only a site of language acquisition for those who had German ancestry. Often parents or siblings were found to engage in informal teaching practices at home (inter-generational/intra-family transmission). This was motivated by their experience that knowledge of 
German can be an important resource on the tight Namibian job market as the more desirable, that is, less strenuous and better paid jobs, were usually available in German-owned businesses and shops. And German employers were known to insist on their staff speaking German to them (and serving German clients using German). Luzia (born in the 1940s, L1 = Otjiherero) described her first encounter with German as follows:

(14) Interviewer: Wo hast du Deutsch gelernt?

Luzia: Nur bei meine mutter, die war schon in die zeit von die Duitse, die hat auch bei die Duitse mense gearbeit, ihre mutter hat bei Duitse mense gearbeit, da hat die immer so gesprechen, dann hat die gesag, bring mir was, eine teller, bring mir, dann hab ich gesag, was is teller, dann weiss ich nie, dann hat die gesag, das is teller, die hat mir immer so, die hat uns immer so gelern, so bissen, bissen gelern.

Interviewer: 'Where did you learn German?'

Luzia: 'Only from my mother, she lived in the time of the Germans, she also worked for German people, her mother had worked for German people, then she always spoke this way, then she said, bring me something, a plate, bring me, then I said, what is a plate, then I don't know, then she said, this is a plate, she has always, this way, she has always taught us, just a little bit, taught us a little.'

And finally there are those who grew up on farms and came into contact with German at an early age when helping their parents with their daily duties and playing with the farmers' children. Veronika (born in the 1930s, L1 = Khoekhoe) describes her childhood on a farm owned by a German-speaking family:

(15) Ich hab nur bei Duitse leute gross geword, in kiche, wir ham immer in das haus mit die kleine kinder auch gespielt un wir ham immer Duits gereden, weisst du, ich bin so gross geworden [...] wir ham immer so mitgespielt, so rumgehn in busch, da was auch eine damm gewesen, da bei die farm, un da hab ich auch immer geswimm mit die kinder, das war gut gewesen. 
'I just grew up with German people, in the kitchen, we always played with the small children, in the house, and we always spoke German, you know, I grew up that way [...] we also played with one another, walked around in the bush, there was also a dam, there at the farm, and there I swam with the children, that was good.'

\subsection{Learning German as Adults.}

For most speakers, however, extensive L2 acquisition took place after they had entered the workforce. This usually happened around ages 12 to 16. As recalled by Heinrich (born in the 1930s, L1 = Otjiherero):

(16) Von die sule aus ham wir immer so helfe arbeit bei die Duitse leute gesucht und da ham wir Duits gelern, wir ham in store gearbeitet un gartenarbeit, im garten gearbeitet, und haushelfe, und alles ham wir gemacht.

'From school we have always looked for help-work with German people, and that's where we learnt German, we worked in the store and garden work, worked in the garden, and house-help, we did everything.'

Martha (born in the 1930s, L1 = Oshiwambo) describes her first day at work, as well as the subsequent learning process, as follows:

(17) Ja, ich hab in Swakopmund gelern, in die haus, wann diese alte Duitse, die konn nich Afrikaans sprechen, nur Duitse, und dann sag die 'Martha, hol mal, eh, hol mal teller', ich bring ein koffie, 'nein das is nicht', ich muss, dann lern ich, oh, das is ein teller, das is ein tasse, das is ein, so hab ich gelern.

'Yes I have learnt [German] in Swakopmund, in the house, when this old German, this one couldn't speak Afrikaans, only German, and then this one says: "Martha, bring, eh, bring a plate," I bring a cup of coffee, "no, that isn't." I have to, then I learn, oh, this is a plate, this is a cup, this is a, that way I learnt.' 
These acquisition narratives are similar across speakers and seem culturally focused-sometimes they are about a plate, sometimes a cup, sometimes they are about the difference between flowers and carrots, which one was asked to fetch from the garden. It is this particular domestic context of acquisition that has given rise to the emic term Kiche Duits. Nicodemus (born in the 1920s, L1 = Khoekhoe) explains the origin of the language name as follows:

(18) Bei kiche nich, da musst Du lern, gib den gabel, gib den, diese becher, das is bei die kiche arbeiten, kiche auf Duits, diese art von lernen, das is die kiche, Kiche Duits, ehm, so is das, die lern-lern Duits, das is die, nich so viel zeug nie, aber nur da wo hast du die, en was kos die [laughter] un wo is deine mutter, so, das is die Kiche Duits und doch auch die grosse Duits, ja, was, auch die grosse Duits, was uns nich versteht.

'In the kitchen, there you must learn, give the fork, give the, this mug, that is working in the kitchen, kitchen in German, this way of learning, that is the kitchen, kitchen German, ehm, it's like that, they learn-learn German, that is the, not so many things, but only where do you have, and how much does this cost [laughter], and where is your mother, so, that is Kitchen German, but also the big German, ja, what, also the big German, which we don't understand.'

The contrast between 'big German' and Kiche Duits, which Nicodemus describes in this extract, reflects a clearly perceived boundary between native and non-native forms of German in Namibia; a boundary which is also reflected in a number of common qualifiers which speakers use to describe their knowledge of German: nur ein bisschen ('just a little bit'), nicht ganz ('not fully'), so biekie-biekie ('just little-little), so halb ('just half'), halb-Duits ('Half-German') or ich probier maar ('I am but trying').

\section{Within-Group Use: Crossing and Performance.}

Participants used German mostly at work with their German employer(s). However, Kiche Duits was more than a lingua franca for out-group communication. Isolated phrases such as wie geht's? ('how are you?'), 
gut geschlafen? ('did you sleep well?), mahlzeit ('enjoy your meal', 'good day'), was machs-du? ('what are you doing?'), angenehme ruhe ('rest well'), verzeihung ('sorry') or tschüss ('bye') are regularly heard in the urban townships. These expressions are used not only by speakers of Kiche Duits but across township residents, irrespective of their proficiency in German. Just like English and Afrikaans, German thus occupies a place within linguistic repertoires, and expresses pragmatic and symbolic meanings within the substrate community.

Apart from pragmatic rituals such as greetings and apologies, there exist in-group contexts where Kiche Duits is used more extensively. Interview extracts 19-23 illustrate these uses which show an appropriation of the former colonial language within local community contexts such as competition games, conversational banter, swearing, the keeping of secrets, and codeswitching (see Pennycook, 2001, for a useful discussion of the notion of "appropriation" in sociolinguistics; also Rogers 2006 and Park \& Wee 2008).

(19) Competition Games

a. Erwin (born in the 1940s, L1 = Khoekhoe; E = Erwin, I = Interviewer; switches into English in italics)

E: Da is stief leute, wir sprech Duits

I: Miteinander?

E: Ja, da is viele leute in Kattatura, aber die hat auch nie in sule gehabt, ja, wenn wir bisschen sprechen lass die andere nich hören was wir sprechen, dann sprech wir Duits, [laughter] like a competition, wo wir domino spielen, da sprech wir always Duits, ja sag mal 'ich kann besser Duits sprechen' oder 'ich kann', so was, nur männer.

E: 'There are many people [in the township], we speak German.'

I: 'With one another?'

E: 'Yes, there are many people in Kattatura, but they didn't go to school, yes, when we speak a little so that the others don't hear what we speak, then we speak German, [laughter] like a competition, where we play domino, there we always speak German, ja, say "I can speak German better" or "I can," like this, only men.' 
b. Wilhelm (born in the 1930s, L1 = Khoekhoe; W = Wilhelm, I = Interviewer)

I: Wann sprechen Sie Duits mit anderen leuten?

W: Ja, wenn ich bisschen so besaufen hab, dann kann ich es auch, 'mann, ich spreche Duits, und du nich'.

I: Und was sagen die dann?

W: Da sagt der 'was kanns du mir erzählen in Duits?', da sag ich 'ach du weiss doch, ich hab lernen Duits, mann, ich weiss Duits, mann!' 'Du kanns doch nich Duits sprechen, wo hast du Duits gelern?' 'Ich hab bei E. gearbeiten, hier hab ich gearbeiten, hab ich die Duits gelern. Wo hast du die Duits gelern?' 'Ich hab bei B. Duits gelern, auch bei S. Duits gelern, da hab ich mit die Duitse leute gro-geworden', un so, das is noch die sprache von die saubere, swarze leute - weiss du, so lerns-du noch wenn du noch nich so'n bisschen weiss, die ander weiss so'n bisschen mehr, so lernst du noch bei deine freund etwas.

I: 'When do you speak German with other people?'

W: 'Yes, when I am a little drunk, then I can: "Man, I speak German and you don't."'

I: 'And what do they say?'

W: "Then he says "what can you tell me in German?" Then I say "ach, you know, I have learnt German, man, I know German, man!" "You can't speak German, where did you learn German?" "I have worked for E., I worked here [in Swakopmund], I have learnt German. Where did you learn German?" "I learnt German at B., also learnt German at S., there I grew up with German people," and so, that is still the pure language, black people, you know, and this way you learn also if you don't yet know a little, the other knows a little more, this way you learn something from your friend. 
(20) Conversational Banter (quatsch-quatsch)

a. Hilda (Swakopmund, born in the 1920s, L1 = Afrikaans; $\mathrm{H}=$ Hilda, I = interviewer)

I: Was haben sie mit ihrem mann gesprochen?

H: Nein, wir ham nur Afrikaans zu hause, nich Duits, wir ham, ja, manchmal ham wir so für spass, ham wir so bißchen unterhalten, so bißchen mit Duitse, aber nich mit die kinder, nee.

I: 'What [language] did you speak with your husband?'

$\mathrm{H}$ : 'No, we only spoke Afrikaans at home, not German, we have, yes, sometimes we made a little conversation just for fun, a little with German, but not with the children, no.'

b. Thomas and Petrus (Omaruru, born in the 1930s and 1920s respectively, $\mathrm{L} 1=$ Khoekhoe, $\mathrm{P}=$ Petrus, $\mathrm{I}=$ Interviewer)

I: Und jetzt? Sprechen sie beide zusammen manchmal Duits?

P: Bloß selten und bloß bisschen quatsch-quatsch [laughter], ohne vrouwens und was [laughter].

I: 'And now? Do you sometimes speak German together?'

P: 'Rarely and only a little nonsense, [laughter] without women and what [laughter].'

(21) Swearing/Scolding

Thusnelda and Lina (Windhoek, both born in the 1920s, L1 = Khoekhoe; $\mathrm{T}=$ Thusnelda, $\mathrm{L}=$ Lina)

T: Mein Oupa, die hat, uhh, die hat gesprech soos Duitse leute, die hat ganz so gut gesprech, wenn sie kwaad was, dann sprech sie die Duits [laughter].

L: Meine vater auch, die auch, 'ich werd dir helfen, gleich, ich werd dir helfen, weißt du das?!' Das is meine vater! Wenn wir kinders nich gut gemach und die muss immer sage 'ich werd dir helfen, weißt du, komm mal net!' [laughter].

T: 'My grandfather he has, uhh, he spoke like German people, he spoke very well, when he was angry, then he spoke German [laughter].'

L: 'My father too, he too, "I will help you, now, I will help you, do you know that!?" That's my father! When we children 
didn't do right and he must always say "I will help you, you know, just come now!" [laughter].'

(22) Keeping Secrets

Pauline and Martha (Walvis Baai, both born in the 1930s, L1 = Oshiwambo; $\mathrm{P}=$ Pauline, $\mathrm{M}=$ Martha, $\mathrm{I}=$ Interviewer)

I: Und sie beide, sprechen sie manchmal zusammen Duits?[Both laugh]

P: Wir hat immer bei die Duitse leute gearbeit.

I: Ja. Aber zusammen sprechen sie nich Duits? Immer Ovambo?

$P$ : Nein, nein, nur wir

M: wenn, wenn

$\mathrm{P}$ : wenn wir zu viele vrouwen

M: viele leute, ne

P: und wir will was sagen

M: und ich will nich was sagen

P: die andere muß hören

M: ja

P: dann sprech wir Duits [laughter].

I: 'And you two, do you sometimes speak German with one another? [Both laugh]'

P: 'We've always worked for German people.'

I: 'Yes. But together you don't speak German? Always Ovambo?'

P: 'No, no, only we'

M: 'if, if'

P: 'if we are too many women'

M: 'many people, ne'

P: 'and we want to say something'

M: 'and I don't want to say something'

$\mathrm{P}$ : 'the others must hear'

M: 'yes'

P: 'then we speak German [laughter]).' 
(23) Codeswitching

Flora and her nephew Alvwin (Swakopmund, Flora born in the 1940s, Alvwin in the 1980s, L1 = Afrikaans; F = Flora, L = Alvwin; switches into German underlined, switches into English in small caps)

F: Hy is baie stout. Weet jy wat het hierdie kind gemaak? Daar was hy nog kleine, daar was hy nog kleine. Die Eichholz het tog die slagterij gehad, nou hy het so ' $n$ buckel, ein, ein, richtig eine grosse buckel, ne, da kann der die kop nich oplig, ne, dann sagt der zu Alvwin 'Alvwin, kom daar 'n car aan?' Toe kom 'n car, dann sê Alvwin 'nein!' [laughter]

A: Hy het so gekyk het, ne: 'Alvwin is das gut?' Ek sê 'ja' [laughter]

F: Sien jy hoe stout is Alvwin

A: I was naughty the time [laughter]

F: Alvwin was stout. Ek wil nog koffie hê, is lekker, lekker meine kind

F: 'He was very naughty. Do you know what this child did? I was still small then, he was still small then. The Eichholz who owned the butchery, now he has such a hump, a, a real big hump, ne, then he cannot lift the head, ne, then he says to Alvwin "Alvwin, is there a car coming?" Then there is a car coming, then Alvwin says "no!" [laughter]'

A: 'He looked like this, ne: 'Alvwin, is this good?' I say "yes" [laughter].'

F: 'See how naughty Alvwin is.'

A: 'I was naughty the time [laughter].'

F: 'Alvwin was naughty. I want more coffee, is nice, nice my child.'

Appropriation as a category of sociolinguistic analysis is closely linked to Rampton's (1995) notion of language crossing, and Bakhtin's (1981 [1935]) work on ventriloquation. Appropriation, crossing, and ventriloquation describe acts of articulating socio-symbolic meanings through other people's voices, usually involving a movement across sharply drawn social and/or ethnic boundaries. Schmidt-Lauber (1998) 
has documented the discursive construction of an exclusive German ethnicity in Namibia: African Namibians, irrespective of their language skills or ancestry, always remained outside of the boundaries of the German Sprachgemeinschaft (speech community; see also Owens 2008). In examples 19-23 speakers challenge this dominant discourse about ownership (of language) and belonging (to a speech community), and express alternative cultural politics through practices of crossing (see also Rogers 2006 on appropriation and cultural resistance). Rampton (1995:280) defines crossing as follows:

[C]ode alternation by people who are not accepted members of the group associated with the second language they employ. It is concerned with switching into languages that are not generally thought to belong to you.

Crossing is a special type of verbal performance, a marked mode of speaking in which individuals purposefully display their multilingual "verbal competencies" (Bauman 1977; see also Pennycook's 2001 discussion of postcolonial performativity). The performative aspect is clearly visible in the speech genres of verbal competition games (19), and conversational banter (20). In both genres it is the speaker's language skills (performance competence) that form the focus of the interaction, not their actual content. Such verbal performances often show qualities of cultural ritual, and reflect "more or less invariant sequences [...] not entirely encoded by the performers" (Rappaport 1999:24, original was emphasized; see also Rampton 2006 on the link between crossing, performance and ritual). Verbal competition games, as visible in 19, contain well-defined sequences of:

(a) asserting one's language skills with reference to their provenance,

(b) challenging the other participants' skills, and

(c) response sequences which follow the same formulae as (a) and (b).

Verbal competition games are particularly prominent among the Namadama, who would construct such games also around their skills in Otjiherero or Oshiwambo.

Ritual and performative qualities are also visible in the use of German for swearing (21). In this case the speech act of swearing is symbolically associated with a particular out-group language and a 
limited number of set phrases. This practice is widespread in Namibia and younger Namibians (who themselves did not know German) repeatedly mentioned their grandparents swearing at them in German. That German employers had a tendency to abuse employees verbally was a reoccurring theme in the interviews (as were memories of the Kommandosprache 'commando language' of the German colonial army, kept alive through stories told by other older relatives; see also section 9, examples 59-61). In-group swearing using German is best interpreted as an instance of "acting German," that is, acting and speaking like the "master" (Adendorff, 2002, reports similar in-group uses of Fanakalo, a South African pidgin).

Example 22 shows that knowledge of German is not only a valuable skill for finding employment in Namibia, but also a resource that allows speakers to keep conversations private (see appendix, flash 1). Example 23 illustrates the use of German as a stylistic device in conversation and narratives, showing both conversational and quotative codeswitching. Conversational codeswitching occurs mainly among those who-like Flora-grew up with German in the family (due to their mixed AfricanGerman heritage). Quotative codeswitching is common across speakers, and occured most typically in "employer-stories," that is, stories about the people one had worked for, their idiosyncracies, and characteristics. These stories often had strongly subversive qualities, making fun of those in power.

During my fieldwork African Namibians repeatedly described themselves as swarze Duitse ('Black Germans') or Duitse jungen ('German boys'), a self-description that reflects the multiplicity of identity brought about by colonial language and culture contacts. Their motivation for claiming "Germanness" was either their mixed AfricanEuropean ancestry, or their life experiences of having worked for Germans for many years, and having thus absorbed, and made their own, aspects of language and culture. The quote at the beginning of this paper articulates this stance succinctly. It comes from an interview with Petrina, an 80 year-old Khoekhoe-speaking woman. Her words, spoken emphatically at the end of our first interview, provocatively question and "cross" the colonial and apartheid boundaries of "race" and language: Ich bin Duitse vrouw. Alte Duitse vrouw sein. Viele Duitse leute gearbeiten ('I am a German woman. An old German woman. I worked for many German people'). 


\section{Non-Linguistic Crossing: Truppenspieler and "Traditional" Dress.} Crossing is not only a linguistic concept, but can be applied to other aspects of social behavior. In Namibia, practices of crossing underpin the construction and expression not only of personal, but also of collective identities that have absorbed and appropriated aspects of the colonial "other." In this section I discuss two cultural practices that have become strong ethnic signifiers, especially among the Ovaherero: the Truppenspieler movement and "traditional" female dress. These complex visualizations of cultural crossing allow us to locate the linguistic practices discussed above in the wider cultural matrix of colonial and postcolonial identities.

\section{TRUPPENSPIELER}

In 1916, one year after the South African military invasion, the new administration received reports about young African men wearing military uniforms and marching to and fro. These practices continued over the years and in 1928 the following eyewitness report was filed by a Sergeant Johannes in Windhoek:

At exactly 12 m.n. on 21.1.28 I was aroused by a Police whistle. I immediately got up and proceeded in the direction of the Damara Location from whence the whistle came. On nearing the Location, I saw a few hundred men lined up and engaged in going through some sort of military drill. At this sight I became very suspicious and decided to watch the performance for a while.

The whole Damara location was in darkness at the time and a big crowd of women and children watched the performance. I was hiding behind a W.C. about 15 yards away from the parade, but I could clearly hear the commands of the instructor. He gave his instructions in the German language, followed by sharp signals from his whistle (Windhoek National Archives A 50/59, 22.1.1928; my emphasis).

These marching groups of Namadama and Ovaherero were called otruppa/oturupa ('troop', Otjiherero borrowing from German), or Truppenspieler, lit. 'troop players'; that is, those who "play" being soldiers by imitating military practices (dress, marching, drills, commandos).

Both Otjiherero- and Khoekhoe-speaking groups had a tradition of militarization. From the 1860s onward they had been organized into 
armed, uniformed, and mounted military units. Upon encountering the German Schutztruppe from the 1880s onward, German military practices and organization became an important point of reference. Already in the 1890s, Jacob Irle, a missionary in Okahandja, described with concern young Ovaherero men, wearing red headbands (to express their allegiance to Chief Samuel Maharero) and "playing" (that is, imitating) German soldiers:

It was as if these red bands had introduced a spirit of rebellion among the youth. People drilled, swore, drank excessively and aped the German soldiers (cited in Werner 1990).

After the Herero-German War, many of those captured were employed as servants, and later soldiers, in the Schutztruppe. There they were, to some extent, "socialized in the confines of the [German] military" (Gewald 1999:265). The structures and traditions of the Schutztruppe became a loose model for the Truppenspieler movement in the aftermath of the war. The sometimes playful military practices of the Truppenspieler should not distract from the sociopolitical aspects of the movement. It functioned as an ethnically based welfare and support organization that brought people from dispersed settlements together, following the destruction of traditional indigenous networks (Werner 1990, Gewald 1999: 263ff).

The German influence on the movement is unmistakable in the hierarchy of ranks and titles: The Kaiser ('emperor') of the regiment was supported by officers and soldiers, all of whom carried German titles: Oberst ('colonel'), Leutnant ('lieutenant'), Wachtmeister ('constable'), Unteroffizier ('corporal'), and Gefreiter ('private'). When the South African Military Magistrate seized some documents belonging to the Kaiser of the Okahandja troop (Eduard Maharero), they found an array of assumed, almost theatrical "German" personas among his chief officers: the "native" Frederick, who worked for Dr Fock, was referred to as Governeur von Deimling, Jimmy and Mattheus who worked at the Gruners and $\mathrm{Mr}$ Kessler respectively were known as Oberstleutnant Leutwein and von Estorff, and finally there was Fritz, who worked for the Reverend during the day, and was called Adjudant Schmetterling von Preusen ('Butterfly of Prussia') at the nightly drills (Windhoek National Archives, A50/59, 19 May 1917). Letters issued by the movement carried the abbreviation M.P.S.M., which stood for Mukuru Puneti 
Samuel Maharero ('God with us and Samuel Mahararo'), a direct translation of the royal Prussian motto Gott mit uns ('God with us').

First evidence of the Truppenspieler movement dates back to 1905; however, it was the funeral of Chief Samuel Maharero (c. 1854-1923), who referred to himself in German as König von Hereroland ('King of Hereroland'), which contributed to the formalization and elevation of these practices:

In Okhahandja, on a cold winter's day in 1923, an honour guard of Herero soldiers dressed in German uniforms, wearing German military ranks, and marching to German commands, carried a coffin to the grave. A military brass band, which played a German funeral march, and 170 mounted Herero soldiers, riding four abreast, preceded the coffin [...]. In effect the funeral, in its outward appearances, was identical to those which had been given to high-ranking German officials [...] full of pomp and ceremony, marching brass bands, mounted soldiers, and massed ranks of soldiers [...]. For the Herero the funeral of Samuel Maharero was the largest socio-political event since the Herero-German war [...]. The funeral demonstrated to the Herero and the outside world that they were once again a self-aware, selfregulating political entity, with their own unique identity (Gewald 1999:274, 279, 282).

A unique identity, one might add, which self-consciously appropriated colonial practices and symbols, reviving their own military traditions through the mirror of their colonial experience (see Ranger 1983 and Spear 2003 for similar observations regarding British colonies in Africa). It was a subversive move, a continuation of the fight against domination: wearing the cloth of the enemy was also believed to weaken his spirit (Hendrickson 1996:227; note that under South African administration uniforms came to include symbols of the new regime).

The Truppenspieler movement is still active today among the Ovaherero and the various troops parade each year on Herero Day in Okahandja. Several of the male speakers included in this study proudly showed me their German-style uniforms, their military passes (complete with German-sounding pseudonyms), and reported early morning marching drills with German commands. The practice has disappeared among Khoekhoe-speaking groups; however, older speakers still remembered these practices to have been alive until the 1960s. 


\section{“TRADITIONAL" DRESS}

Another example of non-linguistic crossing and cultural appropriation is the form of the so-called "traditional" female dress of Namadama and Ovaherero women (Hendrickson 1994).

The garments are visually striking: reminiscent of Victorian-era fashions women wear a heavy dress with long voluminous skirts (supported by several petticoats), a high and tightly bound waist, and billowing long sleeves (figure 3). Added to this is a shawl and a distinctive headdress which is constructed out of two scarves. This style of dress differs markedly from pre-colonial attire (figure 4), as well as the simple, white colonial dresses of domestic servants (figure 2): the colors are bold, the materials patterned, not infrequently showing printed portraits of popular African leaders (Durham 1995:192; see also Ross 2006; this style of dress was reported in the Deutsche Kolonialzeitung already in 1908). When I was conducting fieldwork in 2000 only Namadama women in their 70s and 80s, and Ovaherero women around 50 and older would wear the dress daily. Younger Ovaherero women still wore the dress to important cultural events.
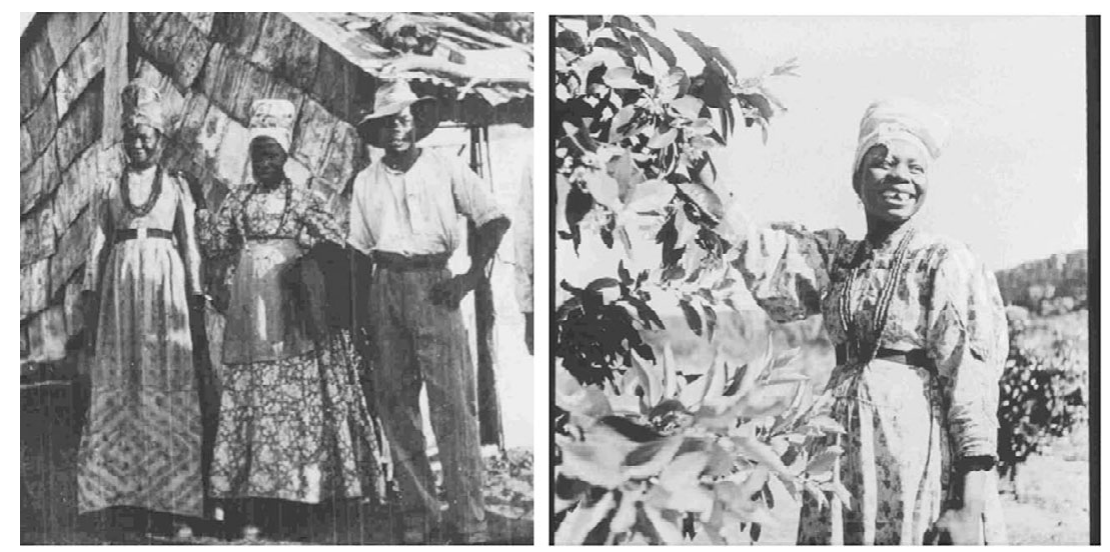

Figure 3. "Traditional" dress, c. 1930s

(1. Koloniales Bildarchiv, no. 028-2305-11; detail from group picture;

r. Koloniales Bildarchiv, no. 028-2305-03). 


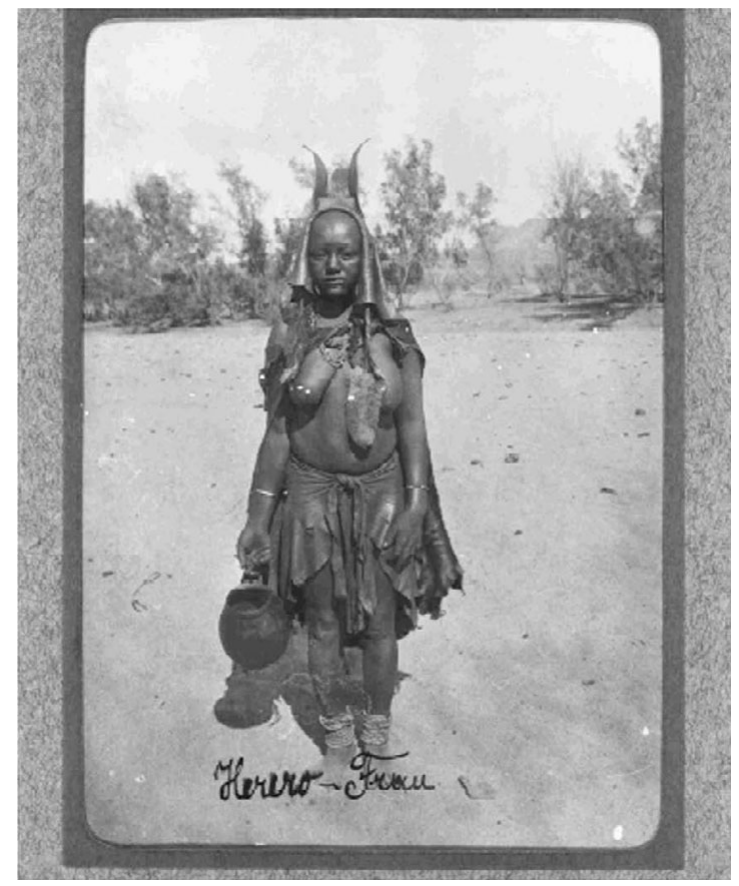

Figure 4. Herero woman, n.d. (Koloniales Bildarchiv no. 071-2999-007).

Today, the long dress is considered "traditional" and a strong marker of ethnic, especially Ovaherero, identity. Yet, its colonial origins are overtly and proudly acknowledged, reflecting the dynamic, and often hybrid, nature of post-colonial tradition in Africa. As noted by Durham (1999: 399-400):

Herero women's reflections on their dress are a counter-example to a widely held notion that tradition (especially outside the West) is necessarily represented as timeless, ineffably local, and autogenetic [...]. Herero occasionally pass time by discussing the transnational aspects of their dress, even when not pestered by anthropologists [...]. In all of these reflections, Herero actively chose and borrowed from other nationalities [...]. Although historical documents talk about a Herero capitulation to European dress in the heavily oppressive conditions following the German-Herero War of 1904, the histories related by Herero women [...] tell of dynamic exchange and positive action, with 
choice and independent agency as central features (see also Durham 1995).

In sum, African Namibians have appropriated various aspects of the cultural "other" - the German colonial heritage-and made them an integral part of their identities. The use of German outside of the expected domain of work is part and parcel of this process, and interacts with new forms of community organization (Truppenspieler) and selfpresentation (dress). In a very "modern" move, the diversity of everyday experiences in a high contact situation has not led to linguistic or cultural fragmentation, nor to assimilation to a dominant culture. Rather, elements from different settings were actively incorporated into a complex, yet integrated personal and collective narrative - a narrative which does not deny the colonial experience, but has transformed this experience into new within-group practices and identities. And it is precisely within these post-colonial practices of cultural and linguistic crossing and appropriation that we can see the seeds for the linguistic stabilization of Kiche Duits.

\section{Language Genesis: The Linguistic Structures of Kiche Duits.}

Although there exists considerable between- and within-speaker variability, we can observe areas of stability, which allow us to identify Namibian Kiche Duits as a linguistic system rather than a mere proficiency continuum of transient interlanguages that are created anew by each individual speaker.

Relative stability, however, does not mean that Kiche Duits constitutes a fixed and uniform linguistic code. The complex reality between variability and stability-which is characteristic of many contact varieties - was described by Schuchardt (1883) in his Kreolische Studien IV with reference to the Spanish creole (Chabacano) of the Philippines:

This español de cocina is of great interest to the linguist. It is not a finished patois, as the Portuguese of Macao or Malacca, it exists in numerous shadings and degrees, with greater or lesser approximation to the Spanish grammar, with greater or lesser use of Malay words; but it is no longer an individual's broken language [...] there is a kind of tradition, one notices a broad average; the Spanish will have to get used to this "Kitchen Spanish" and they themselves will need to employ an intermediate speech level (cited in Bechert \& Wildgen 1991:129). 
"Kitchen" is a common emic qualifier in the history of contact languages. Already in the 16th century the term "kitchen Latin" (coquinaria latinitas) was used to refer to a mixture of Latin syntax and partly vernacular vocabulary (see Burke 2006). In southern Africa, early varieties of Cape Dutch/Afrikaans were referred to as "kitchen Dutch" (kombuis Hollands), and the Nguni-based pidgin Fanakalo was called "kitchen Kaffir" in the early the 20th century; in South Asia, "kitchen English" refers to a range of high-contact varieties of English (Smith 2008:255). What appears common to all these varieties is not only their low prestige and reduced linguistic structure vis à vis the lexifier, but also their highly variable nature. Yet, as noted by Schuchart, behind this variability we can see the emergence of a new norm: a range of common forms that occur across the community and ultimately define a variety separate from the matrilect; in this case, SWD (see also Volker 1989 regarding extensive variation in Unserdeutsch).

\section{STABILITY}

The stability of certain linguistic structures was indicated in interviews when speakers maintained their grammatical variants (such as, for example, the use of an invariant article, unmarked for gender and case) despite my matrilectal model (24).

(24) Interviewer: Wegen der Anna?

'Because of Anna [dative, feminine]?'

Lina: Wegen die Anna.

'Because of Anna [unmarked]'

Particularly interesting were speakers' responses to the Wenker sentences, which they were simply asked to repeat (to test for pronunciation features, see section 5). However, some speakers, clearly dissatisfied with the "big German" model of these sentences, offered "translations" into Kiche Duits. These translations introduced features such as constituent omission (articles, copula), replaced lexical items in line with local norms (for example, mooi), and rephrased the syntactic structure of the model using topic-comment organization. Note that pragmatically motivated syntax is common in Khoekhoe (Haacke 2006), 
as well as in untutored second language acquisition (Klein \& Perdue 1997). See examples 25-27.

(25) Original sentence Tu Kohlen in den Ofen. Damit die Milch zu kochen anfängt.

Kiche Duits Die Kohle bei Ofen. Damit die koche die Milch.

'Put coal in the stove. So that the milk starts boiling.'

(26) Original sentence Das sind schlechte Zeiten. Früher war das Leben besser.

Kiche Duits $\quad$ Ganze schlechte Zeit, ga: nich gut, ne. Ganze mooi onse Zeite. Alte Zeite ganz gut gewesen.

'These are bad times. Life was better before.'

(27) Original sentence Der gute alte Mann ist in das kalte Wasser gefallen.

Kiche Duits Gute alte Mann in kalte Wasser un gefallen.

'The good old man fell into the cold water.'

\section{THE NOUN PHRASE}

Gender and case marking of nouns is generally absent in Kiche Duits. The invariant definite article is die, which is homophonous with the Afrikaans definite article as well as with the German feminine and plural article. The indefinite article is mostly invariant ein (masculine/neuter in German). However, article use is non-obligatory and both definite and indefinite articles can be omitted.

Namibian Kiche Duits shows considerable fluidity in the article system, and use/omission cannot be analyzed in terms of expressing distinctions such as specific/non-specific (article/Ø) and known/unknown (definite/indefinite; as shown, for example, by Platt, Weber, \& Ho 1984, for Singapore English). See examples 28 and 29. 
(28) gesicht is genau wie mens, face is just like person, aber die zähne is so lang but the teeth is so long

'The face looks just like that of a person, but the teeth are very long.'

(29) walvis war so ein kleine stadt gewesen, walvis was so a small town BE-PP jetzt is walvisbaai ganz grosse stadt now is walvisbaai very big town

'Walvis was such a small town, now Walvis Bay is a very big town.'

Noun plurals can be either marked or unmarked, and there is a strong tendency to overgeneralize $-s$, the German, as well as English and Afrikaans, default plural. Occasionally an associated plural, relexified from Afrikaans, is used. See examples 30-33.

(30) Ø marking: vier tochter 'four daughter'

(31) overgeneralization of $-s$ :

zwei tochters 'four daughters' (matrilectal töchter)

mädchens 'girls' (matrilectal mädchen)

swesters 'sisters' (matrilectal schwestern)

(32) relexified associative plural:

meine mama-alle komm von Grootfontein

my mother-all come from Grootfontein

Afrik. my ma-hulle kom van Grootfontein

MY MOTHER-THEM COME FROM GROOTFONTEIN

'My mother and her family come from Grootfontein.' 
(33) matrilectal German plural:

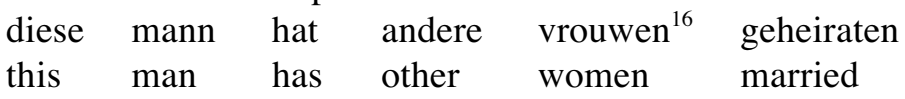

'This man married other women.'

Possession can be marked in four different ways in Kiche Duits. Most common is a periphrastic possessive, which is also widespread in SWD (see section 3). However, while it is obligatory in the matrilect to mark the possessive pronoun for gender and number, Kiche Duits uses the invariant pronoun sein ('his') for all antecedents. This parallels the situation in Afrikaans where an invariant possessive (se) is used. See examples 34 and 35 .

$\begin{array}{llll}\text { die } & \text { alte } & \text { sein } & \text { leib } \\ \text { the } & \text { old-man } & \text { poss } & \text { body }\end{array}$

'the old man's body'

(35)

meine vrouw sein naam
my wife poss name
'my wife's name'

A second construction is the simple juxtaposition of possessor and possessed noun. This might be due to interference from Khoekhoe (which allows such constructions, Roberge 1996). However, since Volker reports a similar construction for Unserdeutsch (1989:156), we might also be looking at a universal feature of untutored second-language acquisition, and a common feature of German contact-varieties. See examples 36 and 37.
eine schwarze
sule sulmeister a black school teacher
'a black school's teacher'

\footnotetext{
${ }^{16}$ Note the German, not Afrikaans (vrouwe), plural ending, irrespective of the Afrikaans pronunciation of frau (vrouw 'woman').
} 
(37) mein mutter sein swester sohn my mother poss sister son

'my mother's sister's son'

In addition we find, although rarely, the use of an overt $-s$ genitive which also occurs in matrilectal varieties of Namibian German (38), as well as the von-construction (39), which frequently uses a reflex $-s$ on the possessor.
mein tochters sohn
my daughter-GEN son

'my daughter's son'
(39) mein opa von mein vaters my grandpa of my father-GEN 'my father's grandpa'

In the pronominal system we see two main tendencies: (a) the use of articles instead of pronouns for referential purposes; der 'the-MASC' rather than $e r$ 'he' as in 40 (also common in SWD; see section 3); and (b) the omission of pronouns as in 41 .

(40) nach eine Woche is der gestorben, der is after a week is the-M die-pp the-M is

nur hingefallen weil der alt war, only fall-down-pp because the-M old was, der wollte zu klein-hause gehen dann is der the-m wanted to small-house go-inf then is the-M

hingefallen und bein gebrochen und bei narkose fall-down-pp and leg break-pp and at anesthesia

is der gestorben, weil der schon schwach war is the-M die-pp because the-M already weak was 
'After a week he died, he only fell down because he was old, he wanted to go to the outside toilet, then he fell down and broke a leg, and during anesthesia he died because he was already weak.'

(41) wenn sie von die kirche komm, dann sitzen bissen when they from the church come then sit little-bit

in haus, dann trinken bissen was, lemonade oder in house then drink little-bit something lemonade or so was, und nachher, vier uhr, so fünf uhr such something, and afterwards, four o'clock so five o'clock

dann geht so in die stadt, in die saal, geht da, then go so in the town, in the hall, go there

das is das nun, dann moet die leute nu tanz that is that now, then must the people now dance

'When they come from the church, then (they) sit a little bit in the house, then (they) drink a little bit, lemonade or something like that, and afterwards, four o-clock, around five o'clock, then (they) go to town, to the hall, (they) go there, that is that now, then the people must now dance.'

\section{THE VERB PHRASE}

The obligatory subject-verb agreement of German has been lost and variation between infinitive/plural forms and roots is common (42-44). The high frequency auxiliaries haben ('to have') and sein ('to be'), however, are usually inflected. There was considerable intra- and interspeaker variation regarding the use of verbal inflections.

(42) ich sprechen auch halb-Duits

I speak-INF also half-German

'I also speak half-German.' 
(43) dann sprech sie immer Duits

then speak-ROOT she always German

'Then she always speaks German.'

(44) wir heul, wir sprechen

we cry-ROOT we speak-PL

'We cry, we talk.'

Kiche Duits has three different ways to express past tense: (a) zeromarking (45); (b) the periphrastic perfect construction (AUX plus PP) as in 46; and (c) the past participle alone (47). Of these the AUX plus PP is most commonly used (see Deumert 2003 for a more detailed discussion). High frequency auxiliary verbs (haben, sein) usually occur in the preterite.

(45) Ø marking

opa brockerhoff kenn ich ganz gut

grandpa brockerhoff know I quite well

'I knew grandpa brockerhoff quite well.'

(46) AUX + PP

manchmal hat er mit donkeykarre gekom

sometimes has he with donkey-car come.PP

'Sometimes he came with the donkey-car.'

(47) PP only (see also example 10)

der so viele jahre gearbeit fir herr $\mathrm{C}$.

he so many years work.PP for $\mathrm{mr} C$.

'He worked so many years for Mr C.'

Within narratives speakers frequently vary different expressions of past tense, and variation can express narrative organization (Schiffrin 1981). In 48, Pauline tells of her experiences as a nanny in the house of family $\mathrm{B}$ : in the beginning (orientation) the narrative is marked for past tense; however, as she gets more involved and imitates the voice of the "missis" she moves into the present tense (complication/evaluation part 
of the narrative; see Labov \& Waletzky 1997). She concludes the narrative with a coda in past tense. Unmarked past underlined; perfect $(\mathrm{AUX}+\mathrm{PP})$ in bold; single PPs in small caps; preterite in bold italic.

(48) Ja, die Udo war nur zehn monat wenn ich da GEARBEIT, nachher hab ich ihn immer kindergarten gebracht und dann hol ich ihn auch zurück von kindergarten, dann bleib ich bei ihm, die war zwei, die hat doch das Udo und Inka, aber manchmal hab ich nur der kleine junge aufgepassen und die mädchen hat bei die sule gegangen, und dann hab ich immer gearbeit, so mittag hab ich bisschen essen gemacht, so halb [laughter], die mutter lernt mir immer: 'du musst heute so kartoffeln machen und karotten mit kartoffeln, da musst du fein machen und für die kind geben'

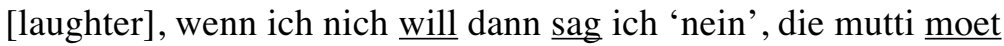
immer abends nur kochen und dann kann ich immer mittags nur warm machen, ja, so was das.

'Yes, the Udo was only ten months old when I worked there, afterwards I always took him to the kindergarten and then I also fetch him, then I stay with him, they were two, they have the Udo and Inke, but sometimes I only looked after the small boy and the girl went to school, and then I always worked, at lunchtime I made a little food, so half [laughter], the mother teaches me always: "today you must make potatoes, and carrots with potatoes, that you must make well and give to the child" [laughter], when I don't want than I say "no," the mother must just cook in the evening and then I can just warm it up at lunchtime, yes, it was like this.'

\section{SYNTAX}

The syntax of Kiche Duits is in line with German, that is, SOV with V2 in declarative clauses. SOV in subordinate clauses is found across the variety spectrum, probably due to influence from Afrikaans, which was known as an L2 by most speakers, and shows the same typological structure as German. However, loss of V-final is common after weil ('because', see 49). This is in line with matrilectal varieties both in Namibia and Germany; also Afrikaans (omdat 'because'). 

(49) weil der war vielleicht bissen frech because the-M was perhaps little-bit cheeky mit sein zweite mutter with his second mother

'Because he was perhaps a little bit cheeky with his stepmother.'

Kiche Duits differs from German with regard to the syntactic position of adverbs. In German unpreposed adverbs must follow the verb and precede existing objects. In Kiche Duits, the adverb occurs in phrasefinal position and does not follow the inflected verb (see 50 and 51).

(50) die leute von duitsland muss auch kommen eigentlich the people from Germany must also come actually 'Actually, the people from Germany must also come.'

$\begin{array}{lllll}\text { (51) die } & \text { kleine } & \text { muss } & \text { essen } & \text { noch } \\ \text { the } & \text { small-one } & \text { must } & \text { eat } & \text { still }\end{array}$

'The small one must still eat.'

Volker (1989:161) reported a similar structure for Unserdeutsch and attributed it to influence from Tok Pisin. In Namibia, Otjiherero would be a likely substrate candidate as adverbials typically occur sentence final. However, before considering substrate influence, one should note that similar constructions are common in SWD and thus formed part of the input. Examples 52 and 53 come from matrilectal SWD speakers.

(52) da war ich zu jung auch then was I to young also

'Then I was also too young' (Deumert, fieldnotes 2000).

(53) die brauchen geld natürlich jetzt the-PL. need money obviously now

'They obviously need now money' (Deumert, fieldnotes 2000). 
Continuity with the matrilectal input is also found in the area of negation (see section 3); that is, the negative adverb nicht follows the modal/AUX and precedes the object (54). In addition, speakers of Kiche Duits show overgeneralization of nich $(t)$ which can replace the negative form of the indefinite article (kein; see 55).

$\begin{array}{lllllll}\text { dann } & \text { konnt } & \text { sie } & \text { nich die } & \text { kinder } & \text { aufheben } \\ \text { the } & \text { could } & \text { she } & \text { not } & \text { the } & \text { children } & \text { pick-up }\end{array}$

'Then she couldn't pick up the children.'

(55) das is ein loch, das is nich haus that is a hole, that is not house

'That is a hole, that is no house. ${ }^{17}$

Kiche Duits allows syntactic focusing (56), including examples of subject copying (57). Focusing or topicalization is a pragmatic structure typical for many contact varieties; it is also common in Khoekhoe (see Haacke 2006).

(56) mit die TV wir ham gehört

with the TV we have hear.PP

'We heard it on the TV.'

\footnotetext{
${ }^{17}$ Similar constructions also occur in SWD; see the following advertisement for the Windhoek restaurant Zum Wirt (2000): Lassen Sie sich von ihrer Frau nicht scheiden, da sie nicht Zeit hat zum Kochen. Essen Sie bei uns und behalten sie Ihre Frau als Hobby ('Don't divorce your wife, because she does not have time to cook. Eat with us and keep your wife as a hobby'). In continental German the bold section would be rendered as da sie keine Zeit zum Kochen hat, that is, use of the negative indefinite article (rather than the negative adverb nicht); the verbal element (AUX) would be in sentence-final position.
} 
(57) hier in walvis baai die leute eers hat die nur here in walvis baai the people first has they only Afrikaans gesprechen Afrikaans speak.PP

'First the people here in Walvis Baai spoke only Afrikaans.'

\section{LEXICON}

The lexicon and and semantics of Kiche Duits show areas of stability and norm formation. As in other contact varieties we find examples of polysemy. Thus, mädchen ('girl') can refer to a 'girl' or a 'woman'; klein ('small') means 'small', 'short', 'soft' but also a small amount of something; gross ('big') can mean 'big', 'loud', 'fat', or a lot of something.

Because of the informal context of language acquisition hypercolloquial lexical items are common. This was particularly noticeable in the translation exercises. For example, the stylistically neutral sentence 'The woman who talks a lot, lives in Windhoek' was translated by one speaker as follows:

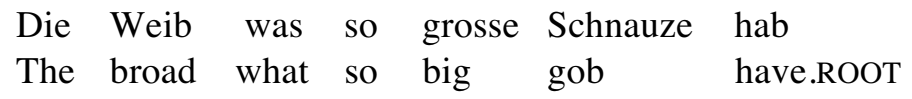

$\begin{array}{llll}\text { die bleib } & \text { in Windhoek } \\ \text { REL. } & \text { stay.root in Windhoek }\end{array}$

'The broad who has a big gob stays in Windhoek.'

The hypercolloquial nature of Kiche Duits was a regular theme in the colonial literature and was typically attributed to negative influence from the German soldiers (for example, Margarete von Schütz, unpublished memoir 1911-1914; Windhoek National Archives, A484; see Moldizio 1998 [1909-1925], Höpker 1997[1936]:8). As already noted in section 7, insulting and disrespectful language was not uncommon in German-run workplaces and formed part of the input throughout the 20th century. Examples 59-61 come from my field notes in 2000. 
(59) Halt die Fresse! (employer to employee)

'Shut your gob!' (highly offensive)

(60) Früher sagte man: Du blöder Kaffer. Das kann man jetzt nicht mehr. Aber blöd bleiben sie doch. (from an interview with an employer)

'In the past we said: You stupid kaffer. Now one can't do that anymore. But they are still stupid.' ("Kaffer" is a highly offensive ethnic slur in southern Africa.)

(61) Haste keine Augen im Kopf, du Dussel!? (employer to employee) 'Don't you have eyes in your head, you dimwit!?'

There also exist lexical elements which are used exclusively by speakers of Kiche Duits, and which do not form part of matrilectal SWD usage. Such items are indicative of independent norm formation within the substrate community. Passione or passion is a noun with the meaning 'visit':

(62) un diese zeit, wenn-a ich auf passion gehen na Windhoek, dann meine geld wenn das wieder geklauten, und, und, und eheh (neg.), die zeit is nich so gut.

'and this time, when I go to Windhoek for a visit, then my money, when they steal it again, and, and, and eheh (neg.), this time is not good.'

Passion(e) is not a borrowing from an indigenous language, but a phonetically modified form of the German word spazieren ('to go for a walk'), showing word-initial consonant cluster simplification. This lexical form has considerable historical depth, and Clara Brockman mentioned it already in 1912 (p. 48):

One should not decline if one's natives come to one on moonlit nights to ask meekly whether they may "passione." (This is an attempt to pronounce the word "spazieren.") 
Another lexical innovation is kulas, meaning 'tasty' or 'delicious'. The expression was used only by older speakers (born in the 1920s); however, many younger speakers knew the word. Nicodemus, the oldest speaker I worked with, laughed when I asked him about kulas. He said that he hadn't heard it in a very long time; it was a word that was common in his youth. He explained its origin as the result of a playful semantic extension (see 63).

(63) Wenn das vleis, vleis, kulas gemach' is, die kulas is die sönste vleis, sönste gute vleis is die kulas, kleingeschneiden vleis, un' darum, darum sag uns wenn die cookie is en das lekkers is, sag uns das is aber kulas ... die smeck aber kulas.

'When the meat, meat-goulash is made, the goulash is the nicest meat, nicest, good meat is the goulash, meat cut into small pieces, and therefore, therefore, we say when the cookie is and this is nice, we say, that is "kulas," this tastes "kulas".'

To conclude, in the structures of Kiche Duits we see well-known language contact processes at play:

(a) regularization and reduction of morphological categories;

(b) substrate influence, which can come from the speaker's L1 as well as Afrikaans, a solid L2 for all speakers;

(c) continuation of SWD superstrate features (especially in lexicon and syntax);

(d) reanalysis and independent norm formation;

(e) universals of second language acquisition.

Given the presence of such structures as well as the language's history (deeply influenced by colonialism's structures of exploitation and oppression), and patterns of usage (inter-ethnic communication and withingroup "crossing"), the question of classification will be discussed in the final section of this paper. What kind of language is Kiche Duits?

\section{Conclusion: A Neo-African Language.}

Whenever I have presented my work on Kiche Duits at conferences and seminars, usually somebody in the audience would ask the question I 
dreaded: "So, is this Kiche Duits a pidgin?" Pondering this question I would be reminded of the popular perceptual illusion in which the brain switches quickly between seeing a young and an old woman, depending on which part of the image one focuses one's attention. Certain contours would support one perception or interpretation, others the alternative. Yet, at no time are the two images truly separate: the "alternating figures interpenetrate each other [...] neither figure is favored over the other" (Boring 1930:444-445). Morphosyntactic reduction, reanalysis, and substrate-based innovations seemed to imply something akin to the notion of a pidgin language. Yet, substantive continuations of superstrate (SWD) features in lexicon and syntax as well as extensive inter- and intra-speaker variation did not easily fit this interpretation.

My difficulty in answering the question was also that, like Mufwene (2000), I felt increasingly uncomfortable with the very act of an expertmotivated baptizing of what I had observed and recorded as "a pidgin," thus ultimately legitimizing my presence at pidgin/creole conferences and elevating myself to "the linguist" who had "discovered" a "new" German pidgin (although, in my initial post-Ph.D. naiveté and enthusiasm such thoughts had indeed crossed my mind; see appendix, flash 2).

At the same time, the very question was problematic since in pidgin/creole studies we are at this stage far removed from the comfort of our earlier sharp and unambiguous definitions (Jourdan 1991). The very distinction between pidgins and creoles became blurred once we moved beyond the "best exemplar" approach and considered contact languages in their complexity (Mufwene 1997). Repeated attempts to identify clear structural/linguistic criteria that would allow us to deter-mine "pidginness"/"creole-ness" have not been successful, and one can only agree with Muysken (1988:300) that what we are dealing with is best described as "just a language" from a linguistic point of view - albeit a language that emerged in a particular socio-historical setting, that is, a society characterized by relations of domination and exploitation within a highcontact environment (Mufwene 2000, Ansaldo \& Matthews 2007). Where does this leave us?

The history of Kiche Duits is, in many ways, typical of language and culture contact in the context of 19th century European colonialism, leading to the restructuring of the lexifier by a disenfranchised substrate community. Mufwene (1997:51) notes: "unless the population learning it is integrated with [the community] speaking it natively (or fluently), the 
lexifier is bound to be restructured." In contact linguistics, the term "restructuring" describes any kind of contact-induced structural modifications, the "degree" of which depends on the historical and social specifics of the contact situation:

The final outcome of this process [of language contact] is a new linguistic code which consists of a variable, fairly subtle mixture of both superstrate and substrate features [...]. If it is true that creoles come in different degrees of "radicalness" [...] then it is implied that this fact positions any individual language on a continuum between varieties closely modeled upon substrate(s) on the one hand and superstrates [...] on the other. In other words, "radical" creoles display many features deviant from their superstrate input forms and/or possibly resulting from substrate transfer; on the other hand, so-called "semicreoles" will have many superstrate-derived properties and but a few patterns or forms derived from the substrate (or universals) (NeumannHolzschuh \& Schneider 2000:6-7).

Whether we consider the macaronic Otjiherero-German jargon, highly mixed Afrikaans-German varieties, or Kiche Duits, we are looking at restructured language forms that were employed for interethnic communication between colonists and the indigenous population. They were media for interethnic communication (MICs) in the sense of Baker 1997.

However, Kiche Duits never developed into a lingua franca among Africans in Namibia (Baker's medium for community solidarity, MCS). Within African society, multilingualism was common practice and language learning in general highly valued. ${ }^{18}$ This reduced the need for a lingua franca within the substrate community. Yet, at the same time, there existed spaces within the substrate where Kiche Duits was usednot for "serious," "content-based" communication, but for play (for example, competition games), social bonding (banter and keeping secrets),

${ }^{18}$ One day I was on my way to interview Franz (L1 = Khoekhoe, born in the 1940s). Just as I arrived at his house, he rushed out and shouted, running past me: Keine Zeit heute, muss lerne Portugees ('No time today, must learn Portuguese'). Puzzled I went inside and asked his wife what was happening. Apparently, a few days ago, people from Angola had moved next door. Franz had then remembered a friend in the township who knew some Portuguese and he was now on his way to learn a little from his friend, so that he could talk to his new neighbors, welcome them, and find out about them. 
and to express socio-symbolic meanings (swearing, codeswitching). These were communicative moments when Kiche Duits took on the meanings of a medium of community solidarity (MCS), for socioexpressive rather than referential-informative purposes.

Foregrounding the social and expressive meanings of Kiche Duits brings to mind Gilman's (1971:271) statement that "the formation of Pidgin English in West Africa cannot be ascribed simply to the exigencies of communication." The sociolinguistic stabilization and norm emergence of West African varieties of pidgin English was not just a consequence of the need for a European-African lingua franca, but was closely linked to the formation of new cultural identities in urban settings:

In every African country there is a large urban population ... which has developed new African ways of living in response to a new urban situation. Some typical examples of new social traits of this kinds are styles of dress, especially for women, using textiles introduced by the Europeans, high life and African jazz played on European instruments, African markets, bars and beerhalls based on money, and a new bride price system, also based on money. All of these things are similar in using some material good introduced by the Europeans, but being themselves recognizably African, not European [...]. We shall call this new society neo-African. It is our view that Pidgin English arose as part of this neo-African society, and not as a result of the needs of Europeans who traded in Africa (p. 275).

There are parallels between Gilman's description and Eckenbrecher's (1940:318) observations of urban African culture in Namibia in the late 1930s:

The natives in Windhoek are city dwellers (Stadtfräcke, lit. 'city dresscoats'). Their township, the tin city, has developed its own 'culture', if one would like to call it such. All their houses are the same size and are made of old tin. The streets are very straight. In the township there is a native hotel, a tea room and a dance hall. They have their own bands which play for them. There is also a bar where they can get special beer which is government-regulated. Male and female natives enjoy resplendent clothing, some also have cars. The old ones among them still have a preference for speaking German [...]. The Windhoek natives seem to have forgotten their old customs and mores. 
The playful within-group use of Kiche Duits interacted with the development of contact-based cultural traits (Truppenspieler, "tradititional" dress, a "new" urban culture) in creating a complex social response to colonial domination, a response which reflects aspects of neo-African society as discussed by Gilman.

However, under South African rule, when Afrikaans-speaking colonists came to form the majority of employers and Afrikaans was agressively promoted in the school system and administration, those who prided themselves on their mastery of Kiche Duits found that the opportunities for use were contracting. What I recorded in 2000 was the end of a long decline of Kiche Duits in Namibia. It is likely that there were times, in the 1910s and 1920s, when there existed the seeds for the emergence of a neo-African language akin to varieties of West African Pidgin, a MCS in the sense of Baker, widely used and reflective of a distinctive cultural and historical identity. The by far most proficient speakers in my sample were born in the 1920s and 1930s, that is, they still experienced extensive (if playful) within-group usage of Kiche Duits as children and young adults (and were typically taught German by older members of their family, see example 14). Much of the data in this paper reflects their linguistic and cultural memories of these earlier days. As Martha said to me at the end of our first interview, grateful for the opportunity to speak Kiche Duits once again: Du hast mein Duits aufgemach ('You opened up my German').

\section{APPENDIX}

Snapshots: Images of a Linguistic Journey

\section{FLASH 1}

As I gather my lecture notes a student approaches me: "I didn't know you speak German? My grandparents also speak German." I look at him with surprise, we have talked before, his family is from Namibia, their home language is Khoekhoe. "They speak German?" I ask. He laughs: "Yes. When they don't want me to hear what they are saying. And also when they drink too much, then they always talk a lot of German!"

\section{FLASH 2}

The library is empty this afternoon. My student's comments have made me curious. Having finished my Ph.D. on the history of Afrikaans a few months 
earlier, I find myself free from the pressures of the dissertation. Books are piled high on my desk, I am reading. No comment anywhere on German-based contact varieties in Namibia. Pacific, yes. Africa, silence. Could there be an unattested German pidgin in Namibia? In the absence of books, there is only one way to find out.

\section{FLASH 3}

On the plane to Windhoek. Is this a wild goose chase? All based on a throwaway comment by a student about his grandparents? Are there many of those in Namibia who use the colonial language for such playful and everyday purposes? How will I find them once I get there?

\section{FLASH 4}

The streets of Kattatura, Windhoek's former African township, are dusty. The air is hot. A man in his 40 s is sitting in the yard in front of his house, relaxing. I lean over the fence: "Excuse me sir, do you know if there are any people around here who speak German?" The man looks up, showing no surprise at my question. He nods, "Go to the house at the bottom of the street, the old lady there speaks German very nice. She worked for Germans."

\section{FLASH 5}

Wi bin van Duitse, da kan wi auch Duits redn ("We come from Germans, then we can also speak German') says a women in her 60s. She is dressed in traditional Ovaherero attire: a heavy, sweeping dress with numerous petticoats; a high and intricately arranged headscarf. Her grandfather-whom she never met - was a member of the German Schutztruppe, the colonial army.

\section{FLASH 6}

I am reading old files in the Windhoek archives: "Bushman Levy ... is 1,65 tall, heavily built and speaks Dutch, German, broken English and has a squint in one eye. The Hottentot Claas is 1,70 tall and heavily built. He is an intelligent man and speaks Dutch, German and English.” (ZBV 687, 1912)

\section{FLASH 7}

By now everyone knows why I am here. The children have made it a game to locate ever more family members who speak German for me: "Ana, Ana, my uncle's older brother, he also speaks German, come with us!"

\section{FLASH 8}

Walking back from the church in Mondesa, the former African township in Swakopmund, Khoekhoe-speaking Lisema greets friends and neighbors, using both Khoekhoe, !Gâitses, matisa? ('How are you?') and German, Hallo, wie geht's? ('Hello! How are you'). 


\section{FLASH 9}

As Lisema enters the yard her next-door neighbor Kleofas leans over the wall and laughs Ach, du kanns doch gar nich Duits! ('Ach, you can't speak German!'). She laughs back at him Oh ja, ich kann, ich probeer! Du kanns nich! ('Oh yes, I can, I am trying! You can't!'). Kleofas challenges her Ich kann gut. Mehr als du! ('I know it well. Better than you!') The banter continues, back and forth.

\section{FLASH 10}

I am visiting Thomas. His home language is Oshiwambo. He laments that the younger Germans in Namibia no longer speak German at work, it is now all English and Afrikaans. He shakes his head in dismay: Deutsche is jetz geezig mit die sprache ('Germans are now stingy with the language').

\section{FLASH 11}

When I return to Thomas' house a week later, his neighbors tell me that he has died during the night. As I come to terms with the news, Mühlhäusler's remarks about "linguistic rescue work" enter my mind.

\section{FLASH 12}

Writing and listening to my field recordings. It is now eight years later and many of those who I spoke to in 2000 have died. And with them the German they used, they played with, in which they took pride at times, and laughed about at other times. I dedicate this paper to all of them.

\section{REFERENCES}

Adendorff, Ralph. 2002. Fankalo: A pidgin in South Africa. In: Language in South Africa, ed. by Rajend Mesthrie, 179-198. Cambridge: Cambridge University Press.

Ansaldo, Umberto, \& Stephen Matthews. 2007. Deconstructing creole: The rationale. Deconstructing creole, ed. by Umberto Ansaldo, Stephen Matthews, \& Lisa Lim, 1-20. Amsterdam: John Benjamins.

Baker, Phillip. 1997. Directionality in pidginization and creolization. The structure and status of pidgins and creoles, ed. by Arthur K. Spears \& Donald Winford, 91-110. Amsterdam: John Benjamins.

Bakthin, Mikhail M. 1981[1935]. The dialogic imagination. Austin: University of Texas Press.

Bauman, Richard. 1977. Verbal art as performance. Prospect Heights: Waveland Press.

Barron, Smythe L. (ed.) 1978. The Nazis in Africa. Lost documents on the Third Reich. Vol. III. North Carolina: Salisbury. 
Bechert, Johannes, \& Wolfgang Wildgen. 1991. Einfuihrung in die Sprachkontaktforschung. Darmstadt: Wissenschaftliche Buchgesellschaft. Beck, Rose Marie. 2006. We speak Otjiherero, but we write English. Disempowerment through language use in participatory extension work. Along the routes of power: Explorations of empowerment through language, ed. by Martin Pütz, Joshua A. Fishman, \& JoAnne Neff-van Aertslaer, 305332. Berlin: Mouton de Gruyter.

Bley, Helmut. 1996. Namibia under German rule. LIT: Hamburg. Boring, Edwin G., 1930. A new ambiguous figure. American Journal of Psychology 42. 444-445.

Brock, Max. 1990. Südwesterdeutsch - Namibian German. An investigation into the nature and usage of the German spoken in Namibia and the language loyality displayed by its speakers. Cape Town: University of Cape Town, Research Project in Sociolinguistics, Faculty of Education.

Brockmann, Clara. 1912. Briefe eines deutschen Mädchens aus Südwest. Berlin: E. S. Mittler \& Sohn.

Burke, Peter. 2006. The hybridization of languages in Early Modern Europe. European Review 14. 105-110.

Cooper, Allan. D. 2006. Reparations for the Herero genocide: Defining the limits of international litigation. African Affairs 106. 113-126.

Cramer, Ernst L. 1942. Die Kinderfarm. Potsdam: Rütten \& Loening.

Cramer, Ada. 1912. Weiss oder Schwarz. Lehr- und Leidensjahre eines Farmers in Südwest im Lichte des Rassenhasses. Berlin: Deutscher Kolonialverlag.

Deumert, Ana. 2003. Markedness and salience in language contact and second language acquisition: Evidence from a non-canonical contact language. Language Sciences 25. 561-613.

Deumert, Ana. 2004. Language standardization and language change - The dynamics of Cape Dutch. Amsterdam: John Benjamins.

Durham, Deborah. 1995. The lady in the logo: Tribal dress and western culture in a Southern African community. Dress and ethnicity. Change across space and time, ed. by Joanne B. Eicher, 183-194. Oxford: Berg.

Durham, Deborah. 1999. The predicament of dress: Polyvalency and the ironies of cultural identity. American Ethnologist 26. 389-411.

Eckenbrecher, Margarete von. 1940. Was Afrika mir gab und nahm. Erlebnisse einer deutschen Frau in Südwestafrika 1902-1936. Berlin: E. S. Mittler \& Sohn.

Engelberg, Stefan. 2008. The German language in the South Seas: Language contact and the influence of language politics and language attitudes. German diasporic experiences: Identity, migration, and loss, ed. by Mathias Schulze, James M. Skidmore, David G. John, Grit Liebscher, \& Sebastian SiebelAchebach, 317-330. Waterloo: Wilfried Laurier University Press. 
Ewest, Ursula. 1999. Pad. Aufzeichnungen aus Südwest-Afrika dem heutigen Namibia. Windhoek: Typoprint.

Garrett, Paul B. 2006. Contact languages as endangered languages. What is there to lose? Journal of Pidgin and Creole Languages 21. 175-190.

Gewald, Jan-Bart. 1999. Herero heroes. A socio-political history of the Herero in Namibia 1890-1923. Ohio: Ohio University Press.

Gilman, Charles. 1979. Cameroonian pidgin English: A neo-African language. Readings in creole studies, ed. by Ian F. Hancock, 269-280. Ghent: StoryScientia.

Gretschel, Hans-Volker. 1995. The status and use of the German language in independent Namibia: Can German survive the transition. Discrimination through language in Africa? Perspective on the Namibian experience, ed. by Martin Pütz, 299-313. Berlin: Mouton de Gruyter.

Gründer, Horst. 1991. Geschichte der deutschen Kolonien. Schöningh: München.

Güldemann, Tom, \& Rainer Vossen. 2000. Khoisan. African languages: An introduction, ed. by Bernd Heine \& Derek Nurse, 99-122. Cambridge: Cambridge University Press.

Kleinz, Norbert. 1981. Die drei germanischen Sprachen Südwestafrikas. Politische und soziologische Gesichtspunkte ihrer Lage und Entwicklung. Wiesbaden: Steiner.

Haacke, Wilfrid H. G. 2006. Syntactic focus marking in Khoekhoe ("Nama/Damara"). ZAS Papers in Linguistics 46. 105-127.

Haacke, Wilfrid H. G., \& Eliphas Eiseb. 1999. Khoekhoegowab-English/ English-Khoekhoegowab Glossay/Mîdi Saogub. Windhoek: Gamsberg Macmillan Publishers.

Haacke, Wilfrid H.G., Eliphas Eiseb, \& Levi Namaseb. 1997. Internal and external relations of Khoekhoe dialects: A preliminary survey. Namibian languages: Reports and papers, ed. by Wilfrid H. G. Haacke \& Edward E. Elderkin, 125-210. Cologne: Köppe.

Harlech-Jones, Brian. 1990. You taught me language. The implementation of English as medium of instruction in Namibia. Cape Town: Oxford University Press.

Hendrickson, Hildi. 1994. The "long" dress and the construction of Herero identities in Southern Africa. African Studies 53. 25-54.

Hendrickson, Hildi. 1996. Bodies and flags: The representation of Herero identity in colonial Namibia. Clothing and difference. Embodied identities in colonial and post-colonial Africa, ed. by Hildi Hendrickson, 213-244.

Durham: Duke University Press.

Hintrager, Otto. 1939. Die Volkszählung in Südwestafrika. Koloniale Rundschau 25. 43-48. 
Höpker, Carl. 1995[1913]. Das Flächengespenst, ed. by Edna Will. Swakopmund: Superprint.

Höpker, Lydia. 1997[1936]. Als Farmerin in Deutsch-Südwest oder Um Scholle und Leben. Swakopmund: Superprint.

Irle, Hedwig. 1911. Unsere schwarzen Landsleute in Deutsch-Südwestafrika. Güterloh: Bertelsmann.

Jamfa, Leonard. 2008. Germany faces colonial history in Namibia: A very ambiguous "I am sorry." The age of apology, ed. by Mark Gibney, Rhoda E. Howard-Hassmann, Jean-Marc Coicaud, \& Niklaus Steiner, 202-215. Pennsylvania: University of Pennsylvania Press.

Jourdan, Christine. 1991. Pidgins and creoles: The blurring of categories. Annual Review of Anthropology 20. 187-209.

Klein, Wolfgang, \& Clive Perdue. 1997. The basic variety (or: couldn't natural languages be much simpler?). Second Language Research 13. 301-347.

Labov, William, \& Joshua Waletzky. 1997. Narrative analysis. Oral versions of personal experiences. Journal of Narrative and Life History 7.3-38. (Special Issue: Oral Versions of Personal Experience: Three Decades of Narrative Analysis, ed. by. Michael G. W. Bamberg)

Mafeje, Archie. 1991. The theory and ethnography of African social formations. The case of interlacustrine kingdoms. London: Coseria.

Maho, Jouni F. 1998. Few people, many tongues. The languages of Namibia. Gamsberg Macmillan: Windhoek.

Moldizio, Hans-Dietrich. 1998[1909-1925]. Das waren noch Zeiten. Südwester Erinnerungen, ed. by K. Budack \& G. von Schuhmann. Windhoek: Namibia Wissenschaftliche Gesellschaft.

Mühleisen, Susanne. 2005. Emil Schwörers Kolonial-Deutsch (1916) Sprachliche und historische Anmerkungen zu einem "geplanten Pidgin" im kolonialen Deutsch Südwest Afrika. Philologie im Netz 31. 30-48.

Mühlhäusler, Peter. 1979. Bemerkungen zur Geschichte und zum linguistischen Stellenwert des "Pidgindeutsch." Deutsche Sprachkontakte in Übersee, ed. by Leopold Auburger \& Heinz Kloss, 59-88. Tübingen: Narr.

Mühlhäusler, Peter. 1983. Notes on the pidgin German of Kiautschou. Papers in Pidgin and Creole Linguistics 3. 139-142.

Mühlhäusler, Peter. 1984. Tracing the roots of pidgin German. Language \& Communication 4. 27-57.

Mühlhäusler, Peter. 1993. German koines: Artificial and natural. International Journal of the Sociology of Language 99. 81-90.

Mühlhäusler, Peter. 1998. How creoloid can you get? Journal of Pidgin and Creole Languages 13. 355-371.

Mufwene, Salikoko. 1997. Jargons, pidgins, creoles, and koines: What are they? The structure and status of pidgins and creoles, ed. by Arthur K. Spears \& Donald Winford, 35-70. Amsterdam: John Benjamins. 
Mufwene, Salikoko. 2000. Creolization is a social, not a structural, process. Degrees of restructuring in creole languages, ed. by Ingrid NeumannHolzschuh \& Edgar W. Schneider, 65-84. Amsterdam: John Benjamins.

Muysken, Pieter. 1988. Are creoles a special type of language? Linguistics: The Cambridge survey. Vol. II. Linguistic theory: Extensions and implications, ed. by Frederick J. Newmeyer, 285-301. Cambridge: Cambridge University Press.

Namibian Census 2001. Population and housing census: Basic analysis with highlights. Windhoek: Central Bureau of Statistics.

Neumann-Holzschuh, Ingrid, \& Edgar W. Schneider. 2000. Introduction: "Degrees of restructuring" in creole languages? Degrees of restructuring in creole languages, ed. by Ingrid Neumann-Holzschuh \& Edgar W. Schneider, 1-18. Amsterdam: John Benjamins.

Nöckler, Herbert. 1963. Sprachmischung in Südwest-Afrika. München: Hueber.

Owens, Jason. 2008. Blood ties and tongue ties: The role of children in shifting the boundaries of Namibia's German-speaking community. Journal of the History of Childhood and Youth 1. 232-249.

Park, Joseph Sung-Yul, \& Lionel Wee. 2008. Appropriating the language of the other: Performativity in autonomous and unified markets. Language and Communication 28. 242-257.

Pennycook, Alistair. 2001. Critical applied linguistics. A critical introduction. Mahwah, New Jersey, \& London: Lawrence Erlbaum Associates

Pinker, Steven. 1999. Words and rules. The ingredients of language. London: Phoenix/Orion.

Platt, John, Heidi Weber, \& Mian Lian Ho. 1984. The new Englishes. London: Routledge.

Pütz, Joe. 2001. Das grosse Dickschenärie, Dickschenärie I \& II - Kommbeind, Riekonndischend, Gemoddifeid und Gesuhpt (Second edition). Swakopmund: Peter's Antiques.

Ranger, Terence. 1983. The invention of tradition in colonial Africa. The Invention of tradition, ed. by Eric Hobsbawm \& Terence Ranger, 211-263. Cambridge: Cambridge University Press.

Rampton, Ben. 1995. Crossing: Language and ethnicity among adolescents. London: Longman.

Rappaport, Roy A. 1999. Ritual and religion in the making of humanity. Cambridge: Cambridge University Press.

Riehl, Claudia. 2004. Sprachkontaktforschung: Eine Einführung. Tübingen: Narr.

Reinecke, John E. 1937. Marginal languages: A sociological survey of the creole languages and trade jargons. Doctoral dissertation, Yale University. Ann Arbor: University Microfilms. 
Roberge, Paul T. 1996. Multilevel syncretism and the evolution of Afrikaans periphrastic possessives with "se." Stellenbosch Papers in Linguistics 30. 123-153.

Rohrbach, Paul. 1907. Deutsche Kolonialwirtschaft. Vol. I: Südwest Afrika. Berlin: Buchverlag der "Hilfe."

Rogers, Richard A. 2006. From cultural exchange to transculturation: A review and reconceptualization of cultural appropriation. Communication Theory 16. 474-503.

Ross, Robert. 2006. Cross-continental cross-fertilization in clothing. European Review 14. 135-147.

Schiffrin, Deborah. 1981. Tense variation in narrative. Language 57. 45-62.

Schmidt-Lauber, Brigitte. 1998. Die verkehrte Hautfarbe. Ethnizität deutscher Namibier als Alltagspraxis. Berlin: D. Reimer.

Oelhafen, Hans von Schöllenbach. 1926. Die Besiedlung DeutschSüdwestafrikas bis zum Weltkriege. Berlin: D. Reimer

Schimming-Chase, Nora. 1995. Nachwort. Namibia und seine Deutschen. Geschichte und Gegenwart der deutschen Sprachgruppe im Südwesten Afrikas, ed. by Walter G. Wentenschuh, 270-271. Göttingen: Hess.

Shah, Sheena. 2007. German in a contact situation: The case of Namibian German. eDUSA 2. 20-45.

Silvester, Jeremy. 2005. "Sleep with a Southwester." Monuments and settler identity in Namibia. Settler colonialism in the twentieth century, ed. by Caroline Elkins \& Susan Petersen, 271-286. London: Routledge.

Smith, Ian. 2008. Pidgins, creoles, and bazaar Hindi. Language in South Asia, ed. by Braj J. Kachru, Yamuna Kachru, \& S. N. Sridhar, 253-268.

Cambridge: Cambridge University Press.

Sokolowsky, Celia. 2004. Sprachenpolitik des deutschen Kolonialismus. Deutschunterricht als Mittel imperialer Herrschaftssicherung in Togo (18841914). Ibidem, Stuttgart: Ibidem.

Spear, Thomas. 2003. Neo-traditionalism and the limits of invention in British colonial Africa. Journal of African History 44. 3-27.

Thomas, Nicholas. 1994. Colonialism's culture: Anthropology, travel, and government. Oxford: Polity.

Volker, Craig. 1982. An introduction to Raboul creole German. Master's thesis. Brisbane: University of Queensland.

Volker, Craig 1989. Raboul creole German syntax. University of Hawai' $i$ Working Papers in Linguistics 21. 153-189.

Volker, Craig. 1991. The birth and decline of Raboul creole German. Language and Linguistics in Melanesia 22(1/2). 143-156.

Von König, B. 1912/1913. Die Eingebornen-Schulen in den Deutschen Kolonien Afrikas und der Südsee. Koloniale Rundschau 1912:257-268, 405417, 529-543, 616-625, 721-732; 1913:5-27. 
Wagner, Willibald. 1935. Comparative lexical study of Sumerian and Ntu ("Bantu"). Stuttgart: Kohlhammer.

Walthers, Daniel Joseph. 2002. Creating Germans abroad: Cultural policies and national identity in Namibia. Ohio: Ohio University Press.

Werner, Wolfgang.1990. "Playing soldiers:" The Truppenspieler movement among the Herero in Namibia, 1915 to ca. 1945. Journal of Southern African Studies 16.485-502.

Werner, Wolfgang. 1998. "No one will become rich." Economy and society in the Herero reserves in Namibia, 1915-1946. (Basel Namibia Studies Series 2.) Basel: Schlettwein.

Department of English Language and Literature, Linguistics Section University of Cape Town

7701 Rondebosch

South Africa

[ana.deumert@gmail.com] 